\title{
Bird species involved in West Nile virus epidemiological cycle in southern Quebec
}

\author{
Ludivine Taieb ${ }^{1}$, Antoinette Ludwig ${ }^{2}$, Nicholas Ogden ${ }^{2}$, Robbin Lindsay ${ }^{3}$, Mahmood \\ Iranpour $^{3}$, C.A. Gagnon ${ }^{4}$, and Dominique Bicout ${ }^{5}$ \\ ${ }^{1}$ Research Group on Epidemiology of Zoonoses and Public Health (GREZOSP), Faculty of \\ Veterinary Medicine, Université de Montréal \\ ${ }^{2}$ Public Health Risk Sciences Division, National Microbiology Laboratory, Public Health \\ Agency of Canada (PHAC) \\ ${ }^{3}$ Zoonotic Diseases and Special Pathogens Division, National Microbiology Laboratory, \\ Public Health Agency of Canada (PHAC) \\ ${ }^{4}$ Swine and Poultry Infectious Disease Research Center (CRIPA), Faculty of Veterinary \\ Medicine, Université de Montréal Saint-Hyacinthe \\ ${ }^{5}$ VetAgro Sup
}

April 28, 2020

\begin{abstract}
There have been many studies of the ecology of West Nile Virus (WNV) in the US, including the role of different bird species as reservoirs and mid-late summer shifts of feeding of Culex pipiens-restuans (CPR) mosquitoes from birds to mammals. It is often assumed that these findings are generalizable to neighbouring regions of Canada where WNV is endemic; however there have been little equivalent studies in Canada to confirm that this is reasonable. Here we construct a priority list of bird species likely involved in the transmission of WNV in the greater Montreal area by combining three sources of data i) results of WNV surveillance in wild (dead) birds in the province (2002-2015); ii) evidence from molecular blood meal analysis that bird species are fed upon by CPR, the primary enzootic vectors of WNV in the region, collected in mosquito surveillance in the study area in 2008 and 2014; and iii) a literature review on evidence of sero-prevalence and host competence of resident bird species. Three lists of 18, 23 and 53 bird species, respectively, from the three data sources, and totalizing 67 bird species were identified as potential WNV reservoirs/amplifiers. Of the 23 species identified from CPR blood meals, Common starlings, American robins, Song and House sparrows ranked the highest as possible WNV reservoirs/amplifiers. In addition, we found using logistic regression that the proportion of blood meals taken from birds compared to mammals by CPR declined significantly with surveillance week. These findings indicate broad similarity in the ecology of WNV between the study region and northeastern US although the relative importance of some bird species as hosts of CPR and WNV in this area may be somewhat different, and field studies are needed to confirm this, and explore the consequences for the risk of WNV to the human population.
\end{abstract}

\section{Main text \\ Introduction}

First described in Uganda in 1937 (Smithburn et al. 1940), West Nile Virus (WNV) is an arbovirus of the Flaviviridae virus family, genus Flavivirus . Responsible for infections in humans and horses, the virus has a transmission cycle involving mosquitoes as vectors and birds as amplifying hosts or reservoirs (Work et al. 1953, Taylor et al. 1956). In North America, the first outbreak occurred in New York in 1999, and then spread rapidly across the continent causing the death of many bird species (Garmendia et al. 2001, Komar 
et al. 2001). In less than four years, the virus spread throughout much of the continental United States, and activity was first reported in Canada in 2001 (Gancz et al. 2004). WNV is now endemic to much of southern Canada, and given the potential severity of the disease in humans and the lack of treatment or a specific vaccine, WNV infection is a major public health problem in Canada, including in the province of Quebec (INSPQ 2016). Most human cases of WNV are reported from Quebec, Ontario and the Prairie provinces and outbreaks of WNV infection occur sporadically (Figure 1) In Quebec, human cases of WNV are mainly reported from the Montérégie, Montréal and Laval regions of southern Quebec (INSPQ 2016). This study focuses on the Montreal area, one of the regions most affected by WNV in Quebec, with $28 \%$ of clinical cases reported between 2002 and 2014 (INSPQ 2016).

The epizootiological cycle of WNV transmission involves bird of several species that act as reservoirs/amplifying hosts and a range of mosquito species that act as enzootic and epizootic vectors of WNV. Mammals such as horses and humans are incidental or dead-end hosts that are not part of the virus transmission cycle because they do not produce viremia sufficient to infect mosquitoes (Dauphin et al. 2004). In southeastern Canada, including Quebec, the main WNV vectors are Culex pipiensand Culex restuans (Ripoche et al. 2017) and these species are thought responsible for transmitting the majority of WNV cases humans in neighbouring parts of the northeastern US (Kilpatrick et al. 2006, Andreadis 2012).

A range of bird species serve as hosts for WNV, and long-distance migration by many species may disperse WNV over long distances (Rappole et al. 2000, Owen et al. 2012, Jourdain et al. 2007, Peterson et al. 2003, Dusek et al. 2009). The importance of birds species as reservoir hosts depends on a combination of factors: i) their susceptibility to infection; ii) the duration of viraemia at levels greater than those needed to infect feeding mosquitoes; iii) the density of naïve individuals (a combination of the density of the species and rates of infection followed by protective immunity); iv) the 'attractiveness' of the species to vector mosquitoes and thus the proportion of mosquito bites per unit of space-time that occur on the species; and v) the rates of mortality, including WNV-specific mortality, of infective individuals.

Experimental studies have shown that several North American bird species are susceptible to WNV, are likely able to transmit the virus by virtue of the level and duration of viraemia, and die due to the infection (Komar et al. 2003). Mortality in wild bird populations, particularly corvids, was used as an early surveillance signal of WNV activity in a given locality as the virus first spread across the US and then Canada (Marra et al. 2004; Thomas-Belachi et al. 2015), and an index of the rates of expected human cases (Veksler et al. 2009). However retrospective analysis suggested that when it first invaded North America, WNV caused mortality in a wide range of bird species (LaDeau et al. 2007).

Studies in the US have taken account of the multiple factors described above, by combining field observations and laboratory experiment results, to conclude that the American Robin is a key reservoir species (Kilpatrick et al. 2006a). Furthermore, studies from the US suggest that the seasonal nature of human WNV cases (with most cases from late summer through to mid autumn) is associated with a shift in mosquito blood meals from birds to mammals during the high risk period, which may be driven by birds beginning their southwards migration at this time (Kilpatrick et al. 2006b). There is, however, little literature to confirm the degree to which studies in the US are directly relevant to Canada.

In this study, we aimed to develop a priority list of bird species likely involved in the circulation of WNV in the region of Montreal, in southern Quebec, Canada. To do so we identified species that breed in the region, and are known to be competent reservoirs, from the literature and dead bird surveillance, and then prioritised these according to field and laboratory data from field studies on the feeding preferences of Culex pipiens-restuans (CPR) mosquitoes, accounting for bird species abundance in the Montreal area. The blood meal analysis data also allowed us to explore the occurrence of seasonal shifts in host-feeding behaviour.

\section{Materials \& Methods}

\section{Study area}

The greater Montreal area is located in the south of the province of Quebec (Figure 2) and in the central 
part of the St. Lawrence Lowlands. The region is bordered to the north by the Canadian Shield and to the southeast by the Appalachians (Fougères et al. 2017). The region is characterized by a temperate continental climate, with cold winters, due to the influence of Arctic air, and hot summers (Fougères et al. 2017). The study area is $30,231.2 \mathrm{~km}^{2}$, and includes the island of Montreal and was limited by the coordinates $46^{\circ} 13^{\prime} 48 \mathrm{~N}, 45^{\circ} 1{ }^{\prime} 12 \mathrm{~N}$, and $74^{\circ} 24^{\prime} 36 \mathrm{~W}$ and $72^{\circ} 23^{\prime} 24 \mathrm{~W}$. In 2011 , the greater Montreal area comprised $21 \%$ of buildings, $40 \%$ cultivated agricultural land and $39 \%$ natural or semi-natural areas, of which $66 \%$ was forest (StatisticsCanada 2016). With 2,900,000 inhabitants, about 45\% of the Quebec province's population, the greater Montreal area is the most densely populated area in Quebec and the second most densely populated city in Canada.

\section{Identification of priority list of wild bird reservoir specie $s$}

To construct the list of possible WNV reservoir and amplifier bird species for the study area, we used an approach by successive augmentation. Starting with a reference list of regional breeding bird species $L_{0}$, the priority list $L_{f}$ of birds that could potentially play a role in the WNV transmission cycle was obtained as, $L_{f}=L_{0} \cap\left[L_{1}+L_{2}+L_{3}-L_{1} \bigcap L_{2}-L_{1} \bigcap L_{3}-L_{2} \bigcap L_{3}+L_{1} \bigcap L_{2} \bigcap L_{3}\right]$, where $\cup$ indicates "union" of data from databases (bringing all species from the databases together), and $\cap$ indicates "intersection" of data from the databases (i.e. where species are in the different databases). $L_{1}, L_{2}$ and $L_{3}$ are respectively the "databases" of i) species identified as infected by WNV in dead bird surveillance; ii) species identified as being targets for $C P R$ blood meals on the basis of blood meal analyses and iii) the species identified as WNV reservoirs by literature review. Clearly, $L_{1}$ is the first basic list that is augmented with species from $L_{2}$ and $L_{3}$ but not already in $L_{1}$. The comparison with $L_{0}$ is a check insuring that selected bird species belong to study area. $L_{0}$ comprised 318 species extracted from the Avibase database (Lepage 2017), which includes all breeding species present in the Montreal area. Species reported as rare $(n=65)$ in the Avibase were excluded from $L_{0}$.

2.1 Wild bird mortality data: list $L_{1}$ : Mortality data were obtained from the Canadian Wildlife Health Cooperative (CWHC) Passive Mortality Monitoring Program (Drebot et al. 2003). The data came from the passive WNV wild bird surveillance program established in Canada since 2001, the first year the WNV circulation was detected in Canada (Lindsay et al. 2003). This "passive" surveillance work is carried out in collaboration with the local population, who are invited to report to the relevant authorities. Dead birds were retrieved and submitted to veterinary diagnostic laboratories (Drebot et al. 2003). In these laboratories, necropsies were performed and selected tissues were tested by PCR for WNV infection (Lindsay et al. 2003, CWHC 2016). The data cover the period 2002-2015 during which time two WNV epidemics occurred in Quebec. The locations where dead WNV infected birds were collected are reported in Figure 2. To rank birds species belonging to $L_{1}$, the standardized mortality ratio, or relative ratio, $\mathrm{RR}_{s}$, for each bird species "s" was calculated as, $\mathrm{RR}_{s}=\frac{m_{s}}{\left(\lambda \times n_{s}\right)}$, where $m_{s}$ is the number of dead birds of species "s" found positive

to $\mathrm{WNV}, n_{s}$ the corresponding sample size and, $\lambda=\frac{\sum_{s} m_{s}}{\sum_{s} n_{s}}$, is the mortality rate under the homogeneous hypothesis; $\left(\lambda \times n_{s}\right)$ being the expected number of dead birds of species "s".

2.2 Blood meal data: list $L_{2}$ Mosquitoes were collected in our study region between 2008 and 2014 as part of a provincial mosquito surveillance program conducted in southern Quebec (INSPQ 2016). Blood meal analysis was conducted only on engorged females of either Culex pipiens or Cx. restuans (CPR)complex in this study. Capture sites of engorged females are shown in Figure 2. The list $L_{2}$ consists of bird species identified as blood meal sources for $C P R$ complex mosquitoes.

Blood-fed mosquitoes were stored individually in $1.5 \mathrm{ml}$ tubes at $-80^{\circ} \mathrm{C}$ until processing. Extraction of DNA was carried out using a protocol described by Molaei et al. (Molaei et al. 2016). Briefly, $200 \mu$ l of DNAzol@) BD (Molecular Research Center, Cincinnati, OH) was added to each tube. Mosquitoes were homogenized with a pestle, followed by the addition of another $200 \mu \mathrm{l}$ of DNAzol BD and $15 \mu \mathrm{l}$ proteinase-K. Tubes were vortexed briefly, incubated at $70^{\circ} \mathrm{C}$ for ten minutes, then centrifuged for ten minutes at $14000 \mathrm{rpm}$. The supernatants were transferred to new $1.5 \mathrm{ml}$ tubes and $3 \mu \mathrm{l}$ of polyacryl carrier (Molecular Research Center, Cincinnati, $\mathrm{OH}$ ) was added to each tube. Tubes were incubated at room temperature for three minutes 
and then $200 \mu \mathrm{l} 100 \%$ ethanol was added. Following mixing by gentle inversion, tubes were incubated on ice for ten minutes then centrifuged for six minutes at $6000 \mathrm{rpm}$. The supernatants were removed, and the remaining DNA pellets were washed twice by the addition of $750 \mu \mathrm{l}$ of $75 \%$ ethanol and two minutes centrifugation at $3000 \mathrm{rpm}$. After final removal of the ethanol, the tubes were left open to allow the DNA pellets to air dry. Once dry, the pellets were resuspended in 20 to $50 \mu \mathrm{l} 1 \mathrm{X}$ TE buffer. DNA extracts obtained from blood-fed mosquitoes were used as templates for amplification of the cytochrome $b$ gene in avian and mammalian species using primers previously described by Molaei et al. (Molaei et al. 2016). Extracted DNA was amplified in $50 \mu \mathrm{l}$ reactions using the Platinum taq DNA polymerase system (Invitrogen, USA) with final concentrations of $1.5 \mathrm{mM} \mathrm{MgCl} 2,200 \mathrm{nM}$ dNTP and $200 \mathrm{nM}$ per primer. Amplification was carried out in the Applied Biosystems GeneAmp PCR System 9700 using the following conditions: denaturation for two minutes at $94^{\circ} \mathrm{C}, 40$ cycles of amplification consisting of 30 seconds at $94^{\circ} \mathrm{C}, 50$ seconds at $55^{\circ} \mathrm{C}$ (mammalian) or $60^{\circ} \mathrm{C}$ (avian), 60 seconds at $72^{\circ} \mathrm{C}$, extension for seven minutes at $72^{\circ} \mathrm{C}$ and then held at $4^{\circ} \mathrm{C}$. The first 100 amplification products were visualized by gel electrophoresis on $1.9 \%$ agarose gel whereas the remaining samples will be run on QIAxcel (Qiagen, Toronto, Canada). Positive samples were purified using the Wizard SV Gel and PCR Clean-up system (Promega, USA) and Sanger sequencing was performed by the NML Genomics Core Facility using Applied Biosystems 3730 xl DNA Analyzer with Big Dye Terminator version 3.1 and pop7 chemistries. Sequence data were analyzed using DNASTAR Lasergene 9 Software and compared to those in the GenBank (NCBI). Sequence data from mosquitoes that have taken multiple host blood meals from different species would result in poor quality sequence data and host species would not be identifiable. However, we expected that these events would be rare because adult female $C P R$ take mostly one single host before digesting the meal and laying eggs.

The species identified are characterized by the proportion $\left(f_{s}\right)$ of all identified CPR blood meals taken from species $s$. The value of $f_{s}$ will depend on the relative density of species $s$ and on the degree to which a species may be particularly attractive to the mosquitoes - if so then mosquito bites on a particular species may be disproportionate to the density of the species. To explore this a feeding preference index can be obtained as (Rizzoli et al. 2015): $p_{s}=\frac{f_{s}}{a_{s}}$, where $f_{s}$ is as defined above and $a_{s}$ is the ratio of the abundance of species $s$ over that of the total density of the birds in the area. Such a $p_{s}$ can be regarded as a relative risk for a bird of being bitten by the mosquito in relation to its relative abundance (Rizzoli et al. 2015). Unfortunately, $p_{s}$ gets higher and diverges when $a_{s}$ tends to zero. Therefore, we use the following definition for the preference index (Balenghien et al. 2011, Bicout 2013), $p_{s}=\frac{a_{s} f_{s}}{\sum_{j=1}^{n} a_{j} f_{j}}$. Likewise, the relative risk for a bird of being bitten by the mosquito relative to the homogeneous abundance is, $\mathrm{RR}_{s}=n \times p_{s}$. Over and under bitten bird species are characterized by $\mathrm{RR}_{s}>1$ and $\mathrm{RR}_{s}<1$, respectively.

The values for $a_{s}$ were obtained from wild bird count data taken from the EPOQ-ebird database, managed in part by the Regroupement Québec Oiseaux (RQO) for the years 2001 to 2016 (https://www.oiseauxqc.org/epoq.jsp) . This database contains more than six million observations made by ornithologists during their daily trips within Quebec. These data are obtained from opportunistic sampling: each observer lists the species observed on a leaflet, as well as the number of individuals of each species. Each leaflet corresponds to an observation site at a given date during a given period as well as to the number of individuals of each species. Locations at which bird counts were made are shown in Fig. 2.

\section{Analysis of seasonal bird-to-mammal feeding shift of CPR mosquitoes}

Culex mosquitoes are predominantly ornithophilic species, i.e. mainly feeding on birds. We investigated whether the feeding preference of the mosquitoes for birds versus mammals changed over the activity season. We considered the fraction (or probability $\pi_{\text {bird }}$ ) of blood meals taken on bird species (= number of blood meals on all bird species only/total number of blood meals over all species (birds and mammals) as a function of week of the year. Logistic regression was used to model the variation of the feeding preference over weeks as follows,logit $\left(\pi_{\text {bird }}\right)=\beta_{0}+\beta_{1}$ week. Statistical analyses were performed using the glm (generalized linear model) function in $\mathrm{R}$ version 1.1.383 ( $\mathrm{R}$ Foundation for Statistical Computinghttp://www.R-project.org).

2.3 Literature review: list $L_{3}$ :Literature research was conducted in August 2017 in five electronic databases: Scopus, Pubmed, CAB Abstract, Embase and Medline. The phrase used for searching in all databases was: 
"(West Nile Fever OR West Nile Virus) AND (Bird* OR Avian) AND (Mortality OR Sero-prevalence OR prevalence OR competence OR capacity OR transmission) AND (USA OR Canada)". All articles published from January 1, 1999 to August 16, 2017 (end of the search) were included in the selection process using criteria on the language, title, and abstract (Table 1). In short, selected studies had to be written either in English or French, dealing with an epidemiological content about bird sensitivity to WNV in Canada and/or the United States. Data on sero-prevalence and host competence were extracted from the retrieved publications. To rank birds species belonging to $L_{3}$, the standardized WNV sero-positive ratio, or relative ratio, $\mathrm{RR}_{s}$, for each bird species "s" was calculated as, $\mathrm{RR}_{s}=\frac{m_{s}}{\left(\lambda \times n_{s}\right)}$, where $m_{s}$ is the number of WNV sero-positive birds of species "s", $n_{s}$ the sample size of tested birds and, $\lambda=\frac{\sum_{s} m_{s}}{\sum_{s} n_{s}}$, is the sero-positive rate under the homogeneous hypothesis; $\left(\lambda \times n_{s}\right)$ being the expected number of WNV sero-positive birds of species "s".

Migratory status (migratory $\mathrm{M}$, resident $\mathrm{R}$ birds or both $\mathrm{M}, \mathrm{R}$ ), wintering and breeding areas were also added. Wintering/breeding areas have been defined as the three main regions of the East Atlantic migration corridor: region of Quebec QC, North USA and South USA, delimited by the northern border of the states of North Carolina and Tennessee (Peterson et al. 2004). The two US areas make it possible to take into account short and long distance migration. These "bird pathways" allow taking in consideration the viral infection origin (wintering zone vs. breeding zone) and the possible role of each bird species in the dispersal of WNV in North America.

\section{Results}

Wild bird mortality data: list $\mathbf{L}_{\mathbf{1}}$

From the passive WNV wild bird surveillance we found a list $L_{1}=18$ that is sorted based on the relative ratio of dead birds positive to WNV (Figure 3). Of all these birds, only 2 (Bald eagle and Blue jay) were found less represented (with the relative ratio of mortality $<1$ ) in mortality data.

Blood meal analysis: list $\mathbf{L}_{2}$

DNA from 273 engorged mosquito samples was extracted although only 263 were included in the study as ten did not have sufficient volume of DNA for amplification with both primer sets. Ninety-seven of $263(36.9 \%)$ were positive using PCR and sequencing with avian primers, whereas 14/263 (5.3\%) were positive with PCR and sequencing using mammalian primers. Ten of 263 extracts (four positives with avian primers and six positives with mammalian primers) were reported as indeterminate, as sequencing of the PCR product was not successful and there was insufficient volume remaining for repeat testing (Table 2).

Twenty-three $\left(L_{3}=23\right)$ different bird species were identified as hosts for CPR mosquitoes (Figure 4). The most frequently bitten bird species (with relative feeding [?] 1) belong to the Passeriformes order, with the American robin $31 \%(\mathrm{n}=30)$ being the most commonly identified, followed by the Common starling $11.3 \%$ $(\mathrm{n}=11)$, the Song sparrow 9.3\% $(\mathrm{n}=9)$ and the Cedar waxwing $8.2 \%(\mathrm{n}=8)$ (Fig. 4, left panel). A large proportion of the bird species (13 out of 23) were represented only by one or two blood meals. White-tailed deer were the most frequently bitten mammal species while two blood meals were from humans in weeks 27 (first week of July) and 32 (first week of August).

Likewise, the most abundant birds (with relative abundance [?] 1) were Common starling 21\%, Red-winged blackbird 10\% follow by Cedar waxwing, American goldfinch, Chipping sparrow, American robin and American crow all with $6 \%$ (Fig. 4, left panel).

To explore the feeding preference of $\mathrm{CPR}$, the list $L_{3}$ is sorted based on the value of $p_{s}$ (Fig. 4, right panel). Of these the highest ranked species (with relative feeding preference [?] 1) are in descending order, Common starling, American robin, Song sparrow and House sparrow. All other bird species are associated with a relative feeding preference lower than 1 suggesting that while very abundant, like Red-winged blackbirds, these species may be disfavoured by CPR mosquitoes (Fig. 4)

Analysis of seasonal bird-to-mammal feeding shift of CPR mosquitoes 
There was a significant shift in the proportion of blood meals obtained from mammals compared to birds with advancing surveillance week (coefficient $=-0.27[95 \%$ confidence interval $=-0.47 ;-0.06], \mathrm{p}<0.01$ ). The shift appeared approximately continuous from week 26, with an odds ratio of change in the proportion of blood meals from birds of $0.76(95 \%$ confidence interval $=0.62-0.94)$ per week (Figure 5).

Literature review: list $\mathbf{L}_{\mathbf{3}}$

The literature search identified a total of 1,244 articles, 23 of which met the selection criteria (Figure 6). As a result, we found a list $L_{1}=53$ that is sorted based on the relative ratio of sero-positives (Figure 7) as follows: 22 birds were found most sero-prevalent (with the relative ratio of sero-positives [?] 1) to WNV of which the top five are Green heron, Cooper's hawk, Red-shouldered hawk, Merlin and Eastern meadowlark (all with the same ratio of about 4). And 21 birds are less sero-prevalent with American redstart as the lowest sero-prevalent ones.

\section{Final list $\mathbf{L}_{\mathbf{f}}$}

The distribution of the species we identified among the lists is as follows: $L_{1}=18$ (mortality data of wild birds), $L_{2}=23$ (blood meal analysis of the $C P R$ ) and $L_{3}=53$ (literature review) with the number of common species, $L_{1} \bigcap L_{2}=2, L_{1} \bigcap L_{3}=7$ and $L_{2} \bigcap L_{3}=20$, and $L_{1} \bigcap L_{2} \bigcap L_{3}=2$ species (American crow and Cooper's hawk) belonging to all three lists. The final list of 67 bird species was obtained as, $67=$ $\left[L_{1}+L_{2}+L_{3}-L_{1} \bigcap L_{2}-L_{1} \bigcap L_{3}-L_{2} \bigcap L_{3}+L_{1} \bigcap L_{2} \bigcap L_{3}\right]=18+23+53-2-7-20+2$, representing $21 \%$ of $L_{0}=318$ species from the Avibase database (Lepage 2017), which includes all the species present in the Montreal area.

Table 3 presents the summary results of the characteristics of each of the 67 bird species of interest selected. Characteristic variables include data on bird mortality, bird abundance and CPR feeding preference, and seroprevalence, host competence, migratory status, wintering and breeding areas extracted from the literature.

\section{Discussion}

In this study, we constructed a priority list of birds potentially involved in the transmission of WNV in the greater Montreal region using data from a literature search, data from wild bird surveillance for WNV and evidence from blood meal analysis of $C P R$ mosquitoes that species are being selected by the mosquitoes as hosts. There were 67 breeding species identified by these data sources, which emphasises the possible complexity of WNV transmission cycles.

Out of the 67 bird species, host competences were documented for 22 species, including eight higher competent (competence > 1) species (from the most to the least competent): Blue jay, Common grackle, House finch, House sparrow, Song sparrow, American robin, American crow and Ring-billed gull. The American crow and Blue jay were considered as an indicator for WNV circulation at the beginning of the epidemics (Ludwig et al. 2010, Foppa et al. 2011, Thomas-Bachli 2020)). In addition to being a good indicator, both species exhibit high viraemia when infected (Komar et al. 2003) with a high mortality rate. The mortality of infected birds shortens the period of virus transmission while this period can last several days for infected and still alive species, during which time mosquitoes can continue to feed on these species. Usually, good amplifying hosts are medium-sensitive to the virus infection. This was demonstrated for WNV amplification in California, using House finch as the host species and Culex tarsalis as the main vector species (Worwa et al. 2019).

Blood meal analysis data identified 23 bird species as hosts for blood meals by $C P R$ mosquitoes. The total sample size of mosquitoes was small, but there is no specific reason we are aware of as to why the lack of detection of a species by this method, and the proportions of blood meals identified to each species, are biased and not a reflection of the proportion of mosquito bites per species.

The most bitten species were, from the most preferred to the least, Common startling, American robins, cedar waxwing, song sparrow and house sparrow. Americam robin has been found in other studies (e.g. Hamer et al. 2009; Kilpatrick 2006b). All except cedar waxwings (to our knowledge) have been shown to be 
competent reservoirs for WNV in at least one study (Table 2). The species other than robins likely play a role in WNV transmission, particularly as some, including some sparrow species, may have greater capacity to transmit WNV (via longer duration and higher viraemia) than robins.

The role of the species other than robins in the transmission of the West Nile virus could also be associated with the participation of vector mosquito species other than CPR which are competent for transmitting the West Nile virus. In eastern Canada, for exampleAedes vexans, a widespread mosquito, has demonstrated a vector competence for the West Nile virus but with a rather mammophilic trophic preference and biting birds occasionally (Ripoche , 2019, Giordano 2018, Andreadis 2004).

Other studies have found that house sparrows are under-represented as mosquito blood meal hosts relative to their densities (Hamer et al. 2009 Kilpatrick et al. 2006b) while here they appeared over represented. To what extent these observations may be driven by regional factors such as climate affecting bird population densities, or are associated with the relatively highly urbanised nature of the study area requires further study. The mosquitoes were collected in routine entomological WNV surveillance in $\mathrm{CO}_{2}$-baited $\mathrm{CDC}$ light traps (Ripoche et al. 2019), and marginally gravid traps that attract greater numbers of gorged mosquitoes (Silver, 2008) were not used. We could not rule out the possibility that this could affect comparisons with results of studies in which gravid traps were used, although different findings of gravid and light traps regarding blood meals has not been reported (Kilpatrick et al. 2006b).

There was a shift in feeding behaviour from birds to mammals as in other studies (Kilpatrick et al. 2006b, 2005 Levine et al. 2016). Almost $100 \%$ of blood meals taken from birds in early summer (week 23) while the bird/mammal ratio decreases between July and September towards mammals. However, as pointed out by others (Hamer et al. 2009) the main shift in mosquito feeding from birds to mammals occurred in parallel with the onset of reported human cases (which in Quebec usually happens during surveillance weeks 28-31:https://www.canada.ca/en/public-health/services/diseases/west-nile-virus/west-nile-virusother-mosquito-borne-disease.html). The date of acquisition of cases reported in human case surveillance is likely up to weeks before the date of reporting in surveillance (Ogden et al. 2019), so while a shift of feeding behavior from birds to mammals (including humans) may contribute to the seasonal pattern of WNV infection in humans, it is unlikely to be the main cause.

\section{Conclusion}

These findings indicate broad similarity in the ecology of WNV in the study region and regions in the US where similar studies have occurred in terms of the range of key avian reservoir host species and seasonal change in host selection by mosquitoes. This work has shed lights on the involvement of American robin and other bird species in the circulation of the West Nile virus in southern Quebec. However, the relative importance of some bird species as hosts of CPR and WNV in the greater Montreal area may be somewhat different to that occurring in northeastern US, and field study is needed to confirm this, and explore the consequences for the risk of WNV to the human population. In addition, studies both in the field and in modeling are necessary to elucidate the roles of each bird, which would help to synthesize and consolidate knowledge in the eco-epidemiology of WNV in this area. Such of kind studies would allow to improve the surveillance, control and management of these vector-borne wildlife diseases, which are becoming increasingly important in North America (Mermel 2020, Shannon 2019, McDonald 2019).

\section{Acknowledgments:}

The authors thank all the workers from MSSS, RQO, CWHC who collect and report data used in this study. This study was funded by Public Health Agency of Canada, ComUE - UGA and IDEX "Universite Grenoble Alpes: Universite de l'innovation". CRIPA is a research center financially supported by the Fonds de recherche Quebec Nature et Technologies (FRQNT)

\section{Ethics Statement}

The authors confirm that the ethical policies of the journal, as noted on the journal's author guidelines page, have been adhered to. No ethical approval was required as this study used data from the literature and from 
Canadian monitoring and surveillance programs.

\section{Conflict of Interest Statement}

The authors declare that the research was conducted in the absence of any commercial or financial relationships that could be construed as a potential conflict of interest.

\section{Author Contributions}

LT: data analysis; drafted and edited the manuscript,

AL: conception and design of the study; drafted and edited the manuscript, drafted the revised final version.

NHO: edited the final version of the manuscript

LRL: molecular analysis, manuscript edition

MI: molecular analysis, manuscript edition

CAG: manuscript edition

DJB: conception and design of the study; drafted and edited the manuscript, drafted the revised final version.

Data availability statement

The data that support the findings of this study are available from the corresponding author upon reasonable request.

\section{ORCID}

Dominique J. Bicout :https://orcid.org/0000-0003-0750-997X

\section{References}

Ahlers, L. R. H. and A. G. Goodman (2018). "The Immune Responses of the Animal Hosts of West Nile Virus: A Comparison of Insects, Birds, and Mammals." Front Cell Infect Microbiol 8 : 96.

Andreadis, T. G. (2012). "The contribution of Culex pipiens complex mosquitoes to transmission and persistence of West Nile virus in North America." J Am Mosq Control Assoc 28 (4 Suppl): 137-151.

Andreadis, T.G., et al., Epidemiology of West Nile virus in Connecticut: a five-year analysis of mosquito data 1999-2003. Vector Borne Zoonotic Dis, 2004. 4(4): p. 360-78.

Baitchman, E. J., M. F. Tlusty and H. W. Murphy (2007). "Passive transfer of maternal antibodies to West Nile virus in flamingo chicks (Phoenicopterus chilensis and Phoenicopterus ruber ruber)." J Zoo Wildl Med 38 (2): $337-340$.

Balenghien, T., Fouque, F., Sabatier, P., and Bicout, D. J. (2011). Theoretical Formulation for Mosquito Host-Feeding Patterns: Application to a West Nile Virus Focus of Southern France. J. Med. Entomol.48 (5): 1076-1090. doi: http://dx.doi.org/10.1603/ME10097

Bicout, D. J. (2013). Le virus du Nil occidental . Versailles, France, Ed. Quae, 239 pp. ISBN : 978-2-75921969-8.

Chuang, T. W., R. G. Knepper, W. W. Stanuszek, E. D. Walker and M. L. Wilson (2011). "Temporal and spatial patterns of West Nile virus transmission in Saginaw County, Michigan, 2003-2006." J Med Entomol 48 (5): 1047-1056.

Crans, W. J., D. F. Caccamise and J. R. McNelly (1994). "Eastern equine encephalomyelitis virus in relation to the avian community of a coastal cedar swamp." J Med Entomol 31 (5): 711-728.

CWHC. (2016). "Le Virus du Nil Occidental." fromhttp://fr.cwhc-rcsf.ca/west_nile_virus.php. 
Dauphin, G., S. Zientara, H. Zeller and B. Murgue (2004). "West Nile: worldwide current situation in animals and humans." Comp Immunol Microbiol Infect Dis 27 (5): 343-355.

Drebot, M. A., R. Lindsay, I. K. Barker, P. A. Buck, M. Fearon, F. Hunter, P. Sockett and H. Artsob (2003). "West Nile virus surveillance and diagnostics: A Canadian perspective." Can J Infect Dis14 (2): 105-114.

Dube, M. C., D. M. Bird, A. Dibernardo, L. R. Lindsay and H. Charest (2010). "Prevalence of West Nile Virus in Wild American Kestrels (Falco sparverius) of Southern Quebec, Canada." Journal of Wildlife Diseases 46 (2): 603-607.

Dusek, R. J., R. G. McLean, L. D. Kramer, S. R. Ubico, A. P. Dupuis, 2nd, G. D. Ebel and S. C. Guptill (2009). "Prevalence of West Nile virus in migratory birds during spring and fall migration." Am J Trop Med Hyg 81 (6): 1151-1158.

EnvironmentCanada. (2018). "Meteorological Service of Canada. Canadian Climate Normals. 1981-2010 Climate Normals \& Averages.", fromhttp://climate.weather.gc.ca/climate_normals/index_e.html.

Foppa, I. M., R. H. Beard and I. H. Mendenhall (2011). "The impact of West Nile virus on the abundance of selected North American birds." Bmc Veterinary Research 7 .

Fougeres, D. and R. Macleod (2017). Montreal: The History of a North American City, McGill-Queen's University Press.

Gancz, A. Y., D. G. Campbell, I. K. Barker, R. Lindsay and B. Hunter (2004). "Detecting West Nile Virus in Owls and Raptors by an Antigen-capture Assay." Emerging Infectious Diseases 10 (12): 2204-2206.

Garmendia, A. E., H. J. Van Kruiningen and R. A. French (2001). "The West Nile virus:its recent emergence in North America." Microbes and Infection 3 (3): 223-229.

Gibbs, S. E., D. M. Hoffman, L. M. Stark, N. L. Marlenee, B. J. Blitvich, B. J. Beaty and D. E. Stallknecht (2005). "Persistence of antibodies to West Nile virus in naturally infected rock pigeons (Columba livia)." Clin Diagn Lab Immunol 12 (5): 665-667.

Gibbs, S. E. J., A. B. Allison, M. J. Yabsley, D. G. Mead, B. R. Wilcox and D. E. Stallknecht (2006). "West Nile virus antibodies in avian species of Georgia, USA: 2000-2004." Vector-Borne and Zoonotic Diseases 6 (1): $57-72$.

Giordano, V. B., W. K. Turner, et al. (2018). "Geospatial Analysis and Seasonal Distribution of West Nile Virus Vectors (Diptera: Culicidae) in Southern Ontario, Canada." International Journal of Environmental Research and Public Health 15(4).

Godsey, M. S., Jr., M. S. Blackmore, N. A. Panella, K. Burkhalter, K. Gottfried, L. A. Halsey, R. Rutledge, S. A. Langevin, R. Gates, K. M. Lamonte, A. Lambert, R. S. Lanciotti, C. G. Blackmore, T. Loyless, L. Stark, R. Oliveri, L. Conti and N. Komar (2005). "West Nile virus epizootiology in the southeastern United States, 2001." Vector Borne Zoonotic Dis 5 (1): 82-89.

Hamer, G. L., U. D. Kitron, T. L. Goldberg, J. D. Brawn, S. R. Loss, M. O. Ruiz, D. B. Hayes and E. D. Walker (2009). "Host selection by Culex pipiens mosquitoes and west nile virus amplification." American Journal of Tropical Medicine and Hygiene 80 (2): 268-278.

INSPQ (2016). "Proposition d'un programme de surveillance entomologique du virus du Nil occidental au Quebec - Avis scientifique.".

Jourdain, E., M. Gauthier-Clerc, D. J. Bicout and P. Sabatier (2007). "Bird Migration Routes and Risk for Pathogen Dispersion into Western Mediterranean Wetlands." Emerging Infectious Disease journal13 (3): 365.

Kilpatrick, A. M., L. D. Kramer, S. R. Campbell, E. O. Alleyne, A. P. Dobson and P. Daszak (2005). "West Nile virus risk assessment and the bridge vector paradigm." Emerg Infect Dis 11 : 425-429. 
Kilpatrick AM, Daszak P, Jones MJ, Marra PP, Kramer LD. Host heterogeneity dominates West Nile virus transmission. Proc Biol Sci. 2006a Sep 22;273(1599):2327-33.

Kilpatrick, A. M., L. D. Kramer, M. J. Jones, P. P. Marra and P. Daszak (2006b). "West Nile Virus Epidemics in North America Are Driven by Shifts in Mosquito Feeding Behavior." PLoS Biol 4 (4): e82.

Kilpatrick, A. M., S. L. LaDeau and P. P. Marra (2007). "Ecology of West Nile Virus Transmission and Its Impact on Birds in the Western Hemisphere." The Auk 124 (4): 1121-1136.

Kilpatrick, A. M., R. J. Peters, A. P. Dupuis, 2nd, M. J. Jones, P. P. Marra and L. D. Kramer (2013). "Predicted and observed mortality from vector-borne disease in small songbirds." Biol Conserv165 : 79-85.

Komar, N., D. J. Dohm, M. J. Turell and A. Spielman (1999). "Eastern equine encephalitis virus in birds: relative competence of European starlings (Sturnus vulgaris)." Am J Trop Med Hyg 60 (3): 387-391.

Komar, N., S. Langevin, S. Hinten, N. Nemeth, E. Edwards, D. L. Hettler, B. S. David, R. A. Bowen and M. L. Bunning (2003). "Experimental Infection of North American Birds with the New York 1999 Strain of West Nile Virus." Emerg Infect Dis 9 (3).

Komar, N., N. A. Panella and E. Boyce (2001). "Exposure of domestic mammals to West Nile virus during an outbreak of human encephalitis, New York City, 1999." Emerg Infect Dis 7 (4): 736-738.

Komar, N., N. A. Panella, J. E. Burns, S. W. Dusza, T. M. Mascarenhas and T. O. Talbot (2001). "Serologic evidence for West Nile virus infection in birds in the New York City vicinity during an outbreak in 1999." Emerg Infect Dis 7 (4): 621-625.

Komar, N., N. A. Panella, S. A. Langevin, A. C. Brault, M. Amador, E. Edwards and J. C. Owen (2005). "Avian hosts for West Nile virus in St. Tammany Parish, Louisiana, 2002." Am J Trop Med Hyg73 (6): 1031-1037.

Komar, N., N. A. Panella, G. R. Young, A. C. Brault and C. E. Levy (2013). "Avian hosts of West Nile virus in Arizona." Am J Trop Med Hyg 89 (3): 474-481.

Kone, P. L., L. and F. Milord (2005). Epidemiologie et effets de l'infection par le virus du Nil occidental sur la sante humaine : mise a jour 2004, INSPQ.

LaDeau, S. L., A. M. Kilpatrick and P. P. Marra (2007). "West Nile virus emergence and large-scale declines of North American bird populations." Nature 447 (7145): 710-713.

Lepage, D. (2017). "Avibase - listes d'oiseaux mondiales Monteregie : Montreal." fromwww.avibase.bsceoc.org/checklist.jsp? region=CAqcmrध̈list=clements\#.

Levine, R. S., D. G. Mead, G. L. Hamer, B. J. Brosi, D. L. Hedeen, M. W. Hedeen, J. R. McMillan, D. Bisanzio and U. D. Kitron (2016). "Supersuppression: Reservoir Competency and Timing of Mosquito Host Shifts Combine to Reduce Spillover of West Nile Virus." Am J Trop Med Hyg .

Lindsay, R., I. Barker, G. Nayar, M. Drebot, S. Calvin, C. Scammell, C. Sachvie, T. La Fleur, A. Dibernardo, M. Andonova and H. Artsob (2003). "Rapid Antigen-Capture Assay To Detect West Nile Virus in Dead Corvids." Emerging Infectious Diseases 9 (11): 1406-1410.

Loss, S. R., G. L. Hamer, E. D. Walker, M. O. Ruiz, T. L. Goldberg, U. D. Kitron and J. D. Brawn (2009). "Avian host community structure and prevalence of West Nile virus in Chicago, Illinois." Oecologia159 (2): 415-424.

Ludwig, A., M. Bigras-Poulin, P. Michel and D. Belanger (2010). "Risk factors associated with West Nile virus mortality in American Crow populations in Southern Quebec." J Wildl Dis 46 (1): 195-208.

Marra, P., S. Griffing, C. Caffrey, A. Kilpatrick, R. McLean, C. Brand, E. Saito, A. Dupuis Ii, L. Kramer and R. Novak (2004). West Nile Virus and Wildlife . 
McDonald, E., M. K. L. Stacey W. Martin, MPH1; Carolyn V. Gould, MD1; Jennifer Lehman1; et al. (2019). "West Nile Virus and Other Domestic Nationally Notifiable Arboviral Diseases - United States, 2018." Morbidity and Mortality Weekly Report 68(31): 673-678.

McLean, R. G. (2006). West nile virus in north American birds.Ornithological Monographs . 60: 44-64.

Mermel, L. A. (2020). "Association of Human Eastern Equine Encephalitis With Precipitation Levels in Massachusetts." JAMA Network Open 3(1): e1920261-e1920261.

Metzger, M. E., J. E. Harbison, J. E. Burns and R. Hu (2012). "Ability of newly emerged adult Culex quinquefasciatus (Diptera: Culicidae) mosquitoes to exit belowground stormwater treatment systems via lateral conveyance pipes." J Med Entomol 49 (2): 343-349.

Nemeth, N. M., G. E. Kratz, R. Bates, J. A. Scherpelz, R. A. Bowen and N. Komar (2008). "Naturally induced humoral immunity to West Nile virus infection in raptors." Ecohealth 5 (3): 298-304.

Nemeth, N. M., P. T. Oesterle and R. A. Bowen (2009). "Humoral immunity to West Nile virus is longlasting and protective in the house sparrow (Passer domesticus)." The American journal of tropical medicine and hygiene 80 (5): 864-869.

Ogden, NH, A Ludwig, AP Morse, H Zheng, H Zhu, 2019, Weather-based forecasting of mosquito-borne disease outbreaks in Canada, Canada Communicable Disease Report 45(5): 127-132.

Owen, J. C., A. Nakamura, C. A. Coon and L. B. Martin (2012). "The effect of exogenous corticosterone on West Nile virus infection in Northern Cardinals (Cardinalis cardinalis)." Vet Res 43 : 34.

Peterson, A. T., D. A. Vieglais and J. K. Andreasen (2003). "Migratory birds modeled as critical transport agents for West Nile Virus in North America." Vector-Borne and Zoonotic Diseases 3 (1): 27-37.

Peterson, R. T. and V. M. Peterson (2004). Les oiseaux du Quebec et de l'Est de l'Amerique du Nord, 5e edition.

Randall, N. J., B. J. Blitvich and J. A. Blanchong (2013). "Association between agricultural land use and West Nile virus antibody prevalence in Iowa birds." J Wildl Dis 49 (4): 869-878.

Rappole, J. H., S. R. Derrickson and Z. Hubalek (2000). "Migratory birds and spread of West Nile virus in the Western Hemisphere." Emerging Infectious Diseases 6 (4): 319-328.

Ripoche, M., A. Ludwig, et al. (2019). "Short-term Forecasting of Daily Abundance of West Nile Virus Vectors Culex pipiens-restuans (Diptera: Culicidae) and Aedes vexans Based on Weather Conditions in Southern Quebec (Canada)." J Med Entomol 56(3): 859-872.Ringia, A. M., B. J. Blitvich, H. Y. Koo, M. Van de Wyngaerde, J. D. Brawn and R. J. Novak (2004). "Antibody prevalence of West Nile virus in birds, Illinois, 2002." Emerg Infect Dis 10 (6): 1120-1124.

Ritchie, B. W. (1997). Avian Viruses: Function and Control, Wiley.

Rizzoli, A., L. Bolzoni, E. A. Chadwick, G. Capelli, F. Montarsi, M. Grisenti, J. M. de la Puente, J. Munoz, J. Figuerola, R. Soriguer, G. Anfora, M. Di Luca and R. Rosa (2015). "Understanding West Nile virus ecology in Europe: Culex pipiens host feeding preference in a hotspot of virus emergence." Parasit Vectors $8: 213$.

Roehrig, J. T., M. Layton, P. Smith, G. L. Campbell, R. Nasci and R. S. Lanciotti (2002). "The emergence of West Nile virus in North America: ecology, epidemiology, and surveillance." Curr Top Microbiol Immunol 267 : 223-240.

Silver, J. B. (2008). CHAP2: Sampling the Egg Population. Mosquito Ecology - Field sampling methods 3rd edition. Springer. Dordrecht, the Netherlands, Springer: p 25-136.

Shannon, E. R., O. M. Kristy, et al. (2019). "Cumulative Incidence of West Nile Virus Infection, Continental United States, 1999-2016." Emerging Infectious Disease journal 25(2): 325. 
Smithburn, K. C., T. P. Hughes, A. W. Burke and J. H. Paul (1940). "A Neurotropic Virus Isolated from the Blood of a Native of Uganda1." The American Journal of Tropical Medicine and Hygienes1-20 (4): 471-492.

StatisticsCanada. (2016). "Land cover and land use Montreal." fromhttp://www.statcan.gc.ca/pub/16-201x/2016000/c-g/c-g03-29-eng.htm.

Taylor, R. M., T. H. Work, H. S. Hurlbut and F. Rizk (1956). "A Study of the Ecology of West Nile Virus in Egypt1." The American Journal of Tropical Medicine and Hygiene 5 (4): 579-620.

Thomas-Bachli, A. L., D. L. Pearl, et al. (2020). "The Influence of Sociodemographic Factors on the Engagement of Citizens in the Detection of Dead Corvids During the Emergence of West Nile Virus in Ontario, Canada." Frontiers in Veterinary Science 6(483).

Thomas-Bachli AL, Pearl DL, Berke O, Parmley EJ, Barker IK. A comparison of West Nile virus surveillance using survival analyses of dead corvid and mosquito pool data in Ontario, 2002-2008. Prev Vet Med . 2015 Dec 1;122(3):363-70.

Veksler, A., M. Eidson and I. Zurbenko (2009). "Assessment of methods for prediction of human West Nile virus (WNV) disease from WNV-infected dead birds." Emerging Themes in Epidemiology 6 : 4-4.

Wheeler, S. S., C. M. Barker, Y. Fang, M. V. Armijos, B. D. Carroll, S. Husted, W. O. Johnson and W. K. Reisen (2009). "Differential Impact of West Nile Virus on California Birds." Condor 111 (1): 1-20.

Work, T. H., H. S. Hurlbut and R. M. Taylor (1953). "Isolation of West Nile virus from hooded crow and rock pigeon in the Nile delta." Proc Soc Exp Biol Med 84 (3): 719-722.

Worwa, G., A. A. Hutton, A. C. Brault and W. K. Reisen (2019). "Comparative fitness of West Nile virus isolated during California epidemics." PLoS neglected tropical diseases 13 (2): e0007135-e0007135.

Table 1. Search strategy for the literature review Table 1. Search strategy for the literature review

Question

Level 1: Language

Q1

Level 2: Title

Q1

Q2

Q3

Q4

Level 3: Abstract

Q1

Q2

Q3

Q4

Q5

Q6

Score $=\mathbf{L 1} \times \mathbf{L 2} \times \mathbf{L 3}$; eligible for score [?] 1
Description

\section{Level 1: Language}

Is the paper written in English or French?

$\mathrm{L} 1=\mathrm{Q} 1$; eligible for $\mathrm{L} 1=1$

Level 2: Title

Does the title mention West Nile terms?

Does the title mention bird terms?

Does the title mention a region of study that is concerned (East Coast

Do the title mention terms related to seroprevalence, prevalence, comp

$\mathrm{L} 2=\mathrm{Q} 1 \times \mathrm{Q} 2(1+\mathrm{Q} 3+\mathrm{Q} 4)$; eligible for L2 [?] 1

\section{Level 3: Abstract}

Does the abstract describe search results rather than a method?

Do the abstract mention terms related to bird mortality?

Do the abstract mention terms related to prevalence or sero-prevalence

Does the abstract mention terms relating to host competence ${ }^{1}$ ?

Does the abstract mention terms relating to host capacity ${ }^{2}$ ?

Does the abstract specify the regions of study: states of the Eastern $\mathrm{m}$ $\mathrm{L} 3=\mathrm{Q} 1 \times \mathrm{Q} 6 \times(1+\mathrm{Q} 2+\mathrm{Q} 3+\mathrm{Q} 4+\mathrm{Q} 5)$; eligible for L3 [?] 1

Score $=$ L1 $\times$ L2 $\times$ L3; eligible for score [?] 1

1 The host competence designates the capability of a host species, birds in this case, of being infected and developing a sufficient viremia for transmitting infectious agents to vectors (Komar et al. 1999). 2 The concept of host capacity brings subtlety to the skill of the host. A competent bird can only be involved in 
the transmission of the virus if it is sufficiently abundant and belongs to the species on which a mosquito competent for WNV feeds (Bicout 2013).

Table 2. Results of the molecular analysis of blood meals

\begin{tabular}{|c|c|c|c|c|c|c|c|}
\hline Species & Family & Order & $\mathrm{N}$ & $\begin{array}{l}\text { Birds }(\%)(\mathrm{n} \\
=97)\end{array}$ & $\begin{array}{l}\text { Mammals } \\
(\%)(\mathrm{n}=14)\end{array}$ & $\begin{array}{l}\text { Total }(\%)(\mathrm{n} \\
=111)^{*}\end{array}$ & \\
\hline Birds & Birds & Birds & Birds & Birds & Birds & Birds & Birds \\
\hline $\begin{array}{l}\text { American } \\
\text { robin } \\
\text { (Turdus } \\
\text { migratorius) }\end{array}$ & Turdidae & Passeriformes & 30 & 30.9 & - & 27.0 & \\
\hline $\begin{array}{l}\text { Common } \\
\text { starling } \\
\text { (Sturnus } \\
\text { vulgaris) }\end{array}$ & Sturnidae & Passeriformes & 11 & 11.3 & - & 9.9 & \\
\hline $\begin{array}{l}\text { Song } \\
\text { sparrow } \\
\text { (Melospiza } \\
\text { melodia) }\end{array}$ & Emberizidae & Passeriformes & 9 & 9.3 & - & 8.1 & \\
\hline $\begin{array}{l}\text { Cedar } \\
\text { waxwing } \\
\text { (Bomby- } \\
\text { cilla } \\
\text { cedrorum) }\end{array}$ & Bombycillidae & Passeriformes & 8 & 8.2 & - & 7.2 & \\
\hline $\begin{array}{l}\text { House } \\
\text { sparrow } \\
\text { (Passer } \\
\text { domesticus) }\end{array}$ & Passeridae & Passeriformes & 7 & 7.2 & - & 6.3 & \\
\hline $\begin{array}{l}\text { Savannah } \\
\text { sparrow } \\
\text { (Passercu- } \\
\text { lus } \\
\text { sandwichensis) }\end{array}$ & Emberizidae & Passeriformes & 4 & 4.1 & - & 3.6 & \\
\hline $\begin{array}{l}\text { Northern } \\
\text { cardinal } \\
\text { (Cardi- } \\
\text { nalis } \\
\text { cardinalis) }\end{array}$ & Cardinalidae & Passeriformes & 3 & 3.1 & - & 2.7 & \\
\hline $\begin{array}{l}\text { Gray } \\
\text { catbird } \\
\text { (Dume- } \\
\text { tella } \\
\text { carolinensis) }\end{array}$ & Mimidae & Passeriformes & 3 & 3.1 & - & 2.7 & \\
\hline $\begin{array}{l}\text { House } \\
\text { finch } \\
\text { (Haemor- } \\
\text { hous } \\
\text { mexicanus) }\end{array}$ & Fringillidae & Passeriformes & 3 & 3.1 & - & 2.7 & \\
\hline
\end{tabular}




\begin{tabular}{|c|c|c|c|c|c|c|}
\hline Species & Family & Order & $\mathrm{N}$ & $\begin{array}{l}\text { Birds }(\%)(\mathrm{n} \\
=97)\end{array}$ & $\begin{array}{l}\text { Mammals } \\
(\%)(\mathrm{n}=14)\end{array}$ & $\begin{array}{l}\text { Total (\%) (n } \\
=111)^{*}\end{array}$ \\
\hline $\begin{array}{l}\text { Black- } \\
\text { capped } \\
\text { chickadee } \\
\text { (Poecile } \\
\text { atricapilla) }\end{array}$ & Paridae & Passeriformes & 3 & 3.1 & - & 2.7 \\
\hline $\begin{array}{l}\text { Red- } \\
\text { winged } \\
\text { blackbird } \\
\text { (Agelaius } \\
\text { phoeniceus) }\end{array}$ & Icteridae & Passeriformes & 2 & 2.1 & - & 1.8 \\
\hline $\begin{array}{l}\text { Common } \\
\text { grackle } \\
\text { (Quiscalus } \\
\text { quiscula) }\end{array}$ & Icteridae & Passeriformes & 2 & 2.1 & - & 1.8 \\
\hline $\begin{array}{l}\text { Red-eyed } \\
\text { vireo } \\
\text { (Vireo } \\
\text { olivaceus) }\end{array}$ & Vireonidae & Passeriformes & 2 & 2.1 & - & 1.8 \\
\hline $\begin{array}{l}\text { Cooper's } \\
\text { hawk } \\
\text { (Accipiter } \\
\text { cooperii) }\end{array}$ & Accipitridae & \multicolumn{2}{|c|}{ Accipitriformes 1} & 1.0 & - & 0.9 \\
\hline $\begin{array}{l}\text { Green } \\
\text { heron } \\
\text { (Butorides } \\
\text { virescens) }\end{array}$ & Ardeidae & Pelecaniformes & 1 & 1.0 & - & 0.9 \\
\hline $\begin{array}{l}\text { Northern } \\
\text { flicker } \\
\text { (Colaptes } \\
\text { auratus) }\end{array}$ & Picidae & Piciformes & 1 & 1.0 & - & 0.9 \\
\hline $\begin{array}{l}\text { American } \\
\text { crow } \\
\text { (Corvus } \\
\text { brachyrhyno }\end{array}$ & Corvidae & Passeriformes & 1 & 1.0 & - & 0.9 \\
\hline $\begin{array}{l}\text { American } \\
\text { yellow } \\
\text { warbler } \\
\text { (Den- } \\
\text { droica } \\
\text { petechia) }\end{array}$ & Parulidae & Passeriformes & 1 & 1.0 & - & 0.9 \\
\hline $\begin{array}{l}\text { Ovenbird } \\
\text { (Seiurus } \\
\text { aurocapilla) }\end{array}$ & Parulidae & Passeriformes & 1 & 1.0 & - & 0.9 \\
\hline $\begin{array}{l}\text { American } \\
\text { goldfinch } \\
\text { (Spinus } \\
\text { tristis) }\end{array}$ & Fringillidae & Passeriformes & 1 & 1.0 & - & 0.9 \\
\hline
\end{tabular}




\begin{tabular}{|c|c|c|c|c|c|c|c|}
\hline Species & Family & Order & $\mathrm{N}$ & $\begin{array}{l}\text { Birds (\%) (n } \\
=97)\end{array}$ & $\begin{array}{l}\text { Mammals } \\
(\%)(\mathrm{n}=14)\end{array}$ & $\begin{array}{l}\text { Total }(\%)(\mathrm{n} \\
=111)^{*}\end{array}$ & \\
\hline $\begin{array}{l}\text { Chipping } \\
\text { sparrow } \\
\text { (Spizella } \\
\text { passerina) }\end{array}$ & Emberizidae & Passeriformes & 1 & 1.0 & - & 0.9 & \\
\hline $\begin{array}{l}\text { Warbling } \\
\text { vireo } \\
\text { (Vireo } \\
\text { gilvus) }\end{array}$ & Vireonidae & Passeriformes & 1 & 1.0 & - & 0.9 & \\
\hline $\begin{array}{l}\text { Mourning } \\
\text { dove } \\
\text { (Zenaida } \\
\text { macroura) }\end{array}$ & Columbidae & Passeriformes & 1 & 1.0 & - & 0.9 & \\
\hline Mammals & Mammals & Mammals & Mammals & Mammals & Mammals & Mammals & Mammals \\
\hline $\begin{array}{l}\text { White- } \\
\text { tailed deer } \\
\text { (Odocoileus } \\
\text { virginianus) }\end{array}$ & Cervidae & Artiodactyla & 7 & - & 50.0 & 6.3 & \\
\hline $\begin{array}{l}\text { Bovine } \\
\text { (Bos } \\
\text { taurus) }\end{array}$ & Bovidae & Artiodactyla & 2 & - & 14.3 & 1.8 & \\
\hline $\begin{array}{l}\text { Cat (Felis } \\
\text { catus) }\end{array}$ & Felidae & Carnivora & 2 & - & 14.3 & 1.8 & \\
\hline $\begin{array}{l}\text { Human } \\
\text { (Homo } \\
\text { sapiens) }\end{array}$ & Hominidae & Primates & 2 & - & 14.3 & 1.8 & \\
\hline $\begin{array}{l}\text { Mule deer } \\
\text { (Odocoileus } \\
\text { hemionus) }\end{array}$ & Cervidae & Artiodactyla & 1 & - & 7.1 & 0.9 & \\
\hline
\end{tabular}

* of the 273 blood meal samples analyzed, 111 resulted in interpretable sequencing while 162 did not. 


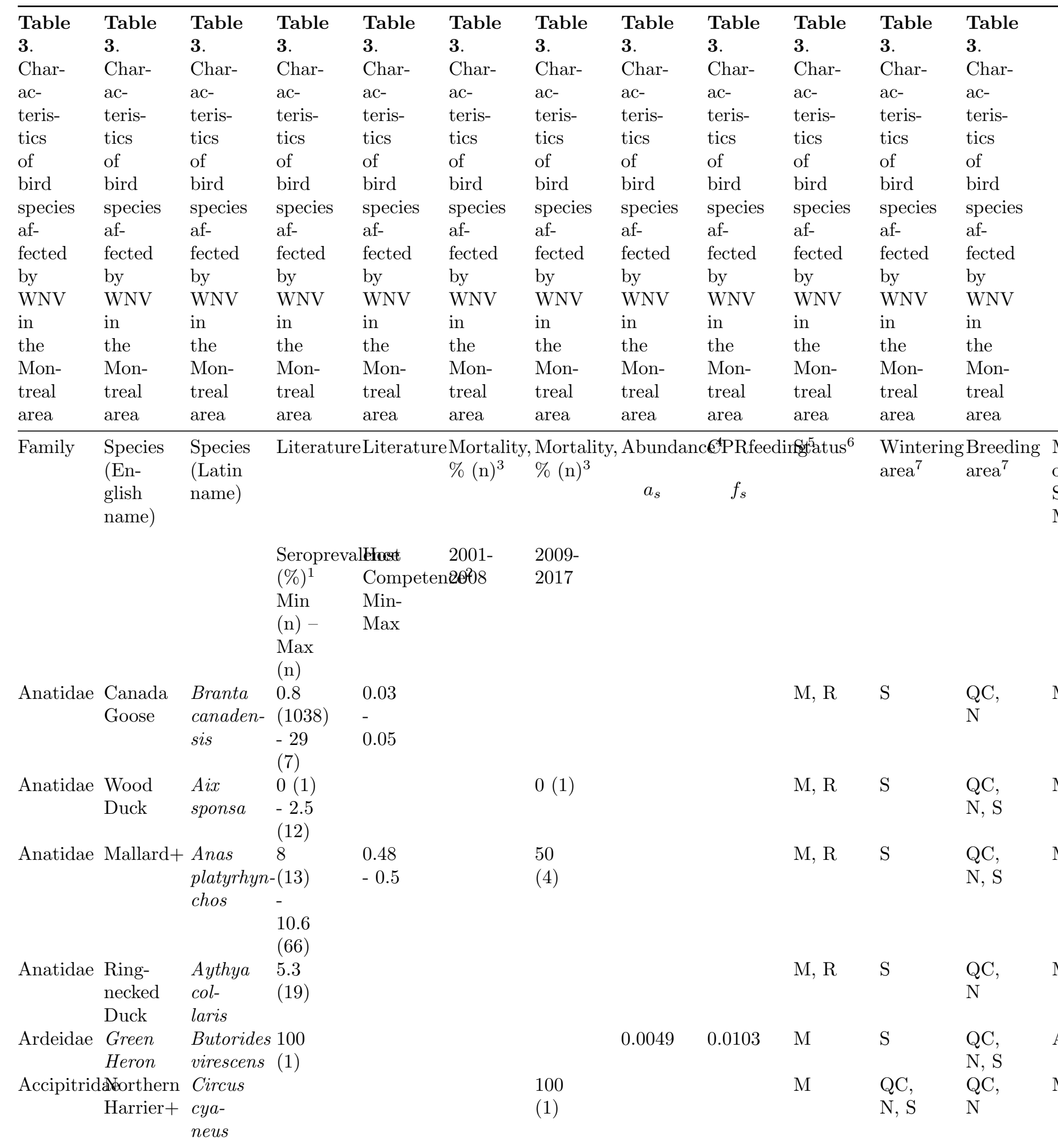




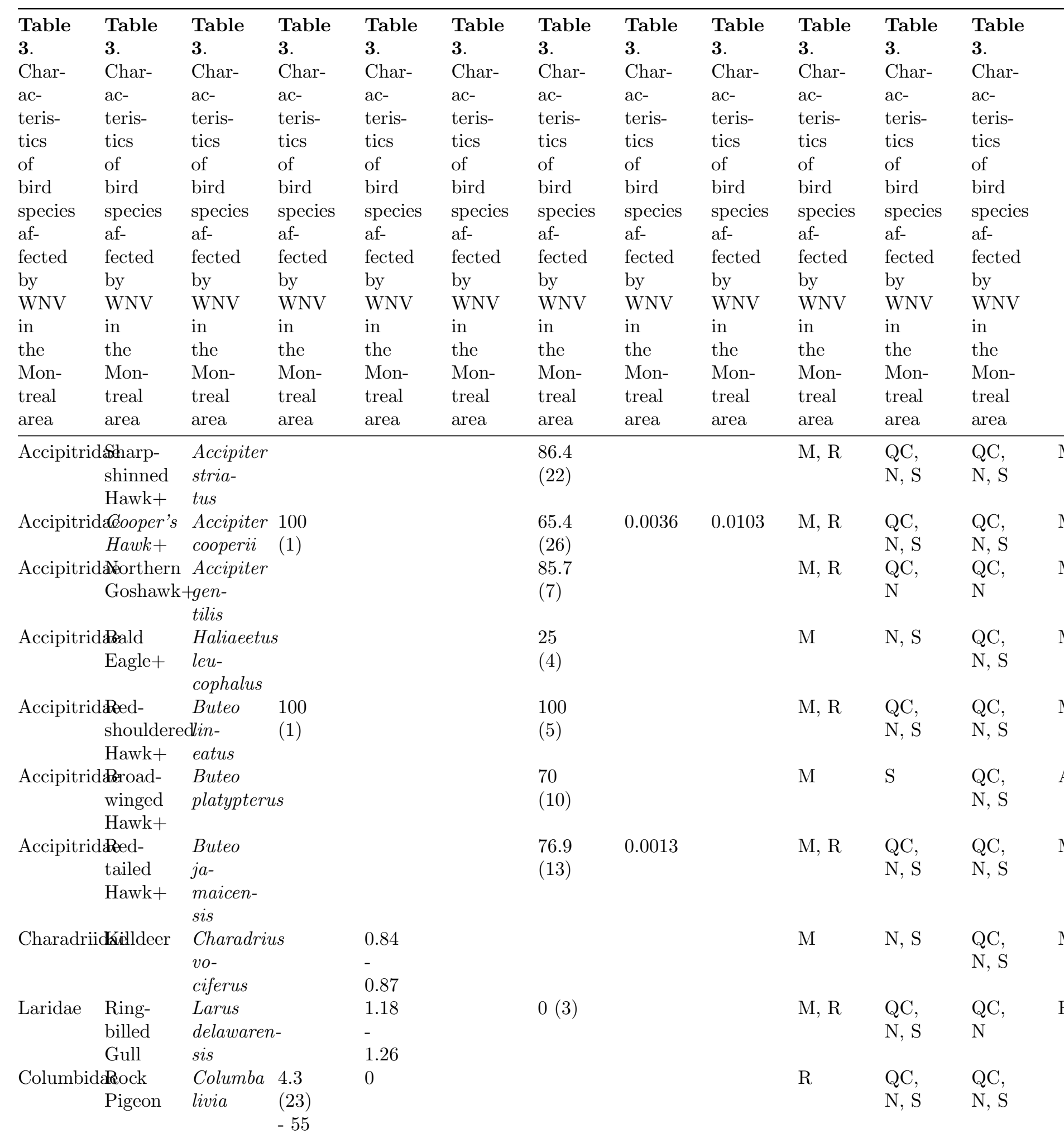




\begin{tabular}{|c|c|c|c|c|c|c|c|c|c|c|c|}
\hline Table & Table & Table & Table & Table & Table & Table & Table & Table & Table & Table & Table \\
\hline & 3. & 3. & & & & & & & 3. & 3. & \\
\hline Char- & Char- & Char- & Char- & Char- & Char- & Char- & Char- & Char- & Char- & Char- & Char- \\
\hline $\begin{array}{l}\text { ac- } \\
\text { teris- } \\
\text { tics }\end{array}$ & $\begin{array}{l}\text { ac- } \\
\text { teris- } \\
\text { tics }\end{array}$ & $\begin{array}{l}\text { ac- } \\
\text { teris- } \\
\text { tics }\end{array}$ & $\begin{array}{l}\text { ac- } \\
\text { teris- } \\
\text { tics }\end{array}$ & $\begin{array}{l}\text { ac- } \\
\text { teris- } \\
\text { tics }\end{array}$ & $\begin{array}{l}\text { ac- } \\
\text { teris- } \\
\text { tics }\end{array}$ & $\begin{array}{l}\text { ac- } \\
\text { teris- } \\
\text { tics }\end{array}$ & $\begin{array}{l}\text { ac- } \\
\text { teris- } \\
\text { tics }\end{array}$ & $\begin{array}{l}\text { ac- } \\
\text { teris- } \\
\text { tics }\end{array}$ & $\begin{array}{l}\text { ac- } \\
\text { teris- } \\
\text { tics }\end{array}$ & $\begin{array}{l}\text { ac- } \\
\text { teris- } \\
\text { tics }\end{array}$ & $\begin{array}{l}\text { ac- } \\
\text { teris- } \\
\text { tics }\end{array}$ \\
\hline & & of & & & & & & & of & of & of \\
\hline $\begin{array}{l}\text { bird } \\
\text { species }\end{array}$ & $\begin{array}{l}\text { bird } \\
\text { species }\end{array}$ & $\begin{array}{l}\text { bird } \\
\text { species }\end{array}$ & $\begin{array}{l}\text { bird } \\
\text { species }\end{array}$ & $\begin{array}{l}\text { bird } \\
\text { species }\end{array}$ & $\begin{array}{l}\text { bird } \\
\text { species }\end{array}$ & $\begin{array}{l}\text { bird } \\
\text { species }\end{array}$ & $\begin{array}{l}\text { bird } \\
\text { species }\end{array}$ & $\begin{array}{l}\text { bird } \\
\text { species }\end{array}$ & $\begin{array}{l}\text { bird } \\
\text { species }\end{array}$ & $\begin{array}{l}\text { bird } \\
\text { species }\end{array}$ & $\begin{array}{l}\text { bird } \\
\text { species }\end{array}$ \\
\hline $\begin{array}{l}\text { af- } \\
\text { fected } \\
\text { by }\end{array}$ & $\begin{array}{l}\text { af- } \\
\text { fected } \\
\text { by }\end{array}$ & $\begin{array}{l}\text { af- } \\
\text { fected } \\
\text { by }\end{array}$ & $\begin{array}{l}\text { af- } \\
\text { fected } \\
\text { by }\end{array}$ & $\begin{array}{l}\text { af- } \\
\text { fected } \\
\text { by }\end{array}$ & $\begin{array}{l}\text { af- } \\
\text { fected } \\
\text { by }\end{array}$ & $\begin{array}{l}\text { af- } \\
\text { fected } \\
\text { by }\end{array}$ & $\begin{array}{l}\text { af- } \\
\text { fected } \\
\text { by }\end{array}$ & $\begin{array}{l}\text { af- } \\
\text { fected } \\
\text { by }\end{array}$ & $\begin{array}{l}\text { af- } \\
\text { fected } \\
\text { by }\end{array}$ & $\begin{array}{l}\text { af- } \\
\text { fected } \\
\text { by }\end{array}$ & $\begin{array}{l}\text { af- } \\
\text { fected } \\
\text { by }\end{array}$ \\
\hline WNV & WNV & WNV & WNV & WNV & WNV & WNV & WNV & WNV & WNV & WNV & WNV \\
\hline in & in & in & in & in & in & in & in & in & & & \\
\hline & & & & the & the & the & the & the & the & the & the \\
\hline $\begin{array}{l}\text { Mon- } \\
\text { treal } \\
\text { area }\end{array}$ & $\begin{array}{l}\text { Mon- } \\
\text { treal } \\
\text { area }\end{array}$ & $\begin{array}{l}\text { Mon- } \\
\text { treal } \\
\text { area }\end{array}$ & $\begin{array}{l}\text { Mon- } \\
\text { treal } \\
\text { area }\end{array}$ & $\begin{array}{l}\text { Mon- } \\
\text { treal }\end{array}$ & $\begin{array}{l}\text { Mon- } \\
\text { treal }\end{array}$ & $\begin{array}{l}\text { Mon- } \\
\text { treal }\end{array}$ & $\begin{array}{l}\text { Mon- } \\
\text { treal }\end{array}$ & $\begin{array}{l}\text { Mon- } \\
\text { treal }\end{array}$ & $\begin{array}{l}\text { Mon- } \\
\text { treal }\end{array}$ & $\begin{array}{l}\text { Mon- } \\
\text { treal }\end{array}$ & $\begin{array}{l}\text { Mon- } \\
\text { treal }\end{array}$ \\
\hline area & area & area & area & area & area & area & area & area & area & area & \\
\hline \multirow{2}{*}{\multicolumn{2}{|c|}{$\begin{array}{c}\text { Columbidadourning } \\
\text { Dove }\end{array}$}} & $\begin{array}{l}\text { Zenaida } \\
\text { macroura }\end{array}$ & $\begin{array}{l}3.8 \\
(26)\end{array}$ & $\begin{array}{l}0- \\
0.19\end{array}$ & & $0(2)$ & 0.0137 & 0.0103 & $\mathrm{M}, \mathrm{R}$ & $\begin{array}{l}\mathrm{QC}, \\
\mathrm{N}, \mathrm{S}\end{array}$ & $\begin{array}{l}\mathrm{QC}, \\
\mathrm{N}, \mathrm{S}\end{array}$ \\
\hline & & & $\begin{array}{l}- \\
57.69 \\
(26)\end{array}$ & & & & & & & & \\
\hline \multirow[t]{4}{*}{ Cuculida } & Yellow- & Cосcуzus & 5.9 & & & & & & M & & QC, \\
\hline & billed & amer- & (17) & & & & & & & & \\
\hline & Cuckoo & $i$ - & -100 & & & & & & & & \\
\hline & & canus & (1) & & & & & & & & \\
\hline \multirow[t]{2}{*}{ Strigidae } & Great & Bubo & 44.4 & 0.68 & & 50 & & & $\mathrm{R}$ & $\mathrm{QC}$, & $\mathrm{QC}$ \\
\hline & $\begin{array}{l}\text { Horned } \\
\text { Owl+ }\end{array}$ & $\begin{array}{l}\text { vir- } \\
\text { gini- } \\
\text { anus }\end{array}$ & (9) & -0.9 & & (6) & & & & $\mathrm{N}, \mathrm{S}$ & $\mathrm{N}, \mathrm{S}$ \\
\hline \multirow[t]{2}{*}{ Strigidae } & Snowy & Bubo & & & & 100 & & & M & $\mathrm{QC}$, & \\
\hline & Owl+ & $\begin{array}{l}\text { scan- } \\
\text { dia- } \\
\text { cus }\end{array}$ & & & & $(2)$ & & & & $\mathrm{N}$ & \\
\hline \multirow[t]{2}{*}{ Strigidae } & Barred & Strix & & & & 66.7 & & & $\mathrm{R}$ & $\mathrm{QC}$, & $\mathrm{QC}$, \\
\hline & Owl+ & varia & & & & (3) & & & & $\mathrm{N}, \mathrm{S}$ & $\mathrm{N}, \mathrm{S}$ \\
\hline \multirow[t]{2}{*}{ Strigidae } & Northern & Aegolius & & & & 50 & & & $\mathrm{R}$ & $\mathrm{QC}$, & $\mathrm{QC}$ \\
\hline & $\begin{array}{l}\text { Saw- } \\
\text { whet } \\
\text { Owl+ }\end{array}$ & $\begin{array}{l}\text { acadi- } \\
\text { cus }\end{array}$ & & & & (8) & & & & $\mathrm{N}$ & $\mathrm{N}$ \\
\hline \multirow[t]{2}{*}{ Picidae } & Hairy & Picoides & 0 & & & & & & $\mathrm{R}$ & $\mathrm{QC}$ & \\
\hline & Woodpecke & $\begin{array}{l}\text { zexillo- } \\
\text { sus }\end{array}$ & $\begin{array}{l}(14) \\
-14.3 \\
(7)\end{array}$ & & & & & & & $\mathrm{N}, \mathrm{S}$ & $\mathrm{N}, \mathrm{S}$ \\
\hline \multirow[t]{3}{*}{ Picidae } & Northern & Colaptes & & 0.06 & & & 0.0178 & 0.0103 & $\mathrm{M}, \mathrm{R}$ & $\mathrm{N}, \mathrm{S}$ & $\mathrm{QC}$, \\
\hline & Flicker & aura- & & & & & & & & & $\mathrm{N}, \mathrm{S}$ \\
\hline & & tus & & 0.14 & & & & & & & \\
\hline \multirow[t]{2}{*}{ Picidae } & Pileated & \multicolumn{2}{|c|}{ Dryocopus 20} & & & & & & $\mathrm{R}$ & $\mathrm{QC}$, & $\mathrm{QC}$, \\
\hline & Woodpeck & $\begin{array}{l}\text { søilea- } \\
\text { tus }\end{array}$ & (5) & & & & & & & $\mathrm{N}, \mathrm{S}$ & $\mathrm{N}, \mathrm{S}$ \\
\hline
\end{tabular}




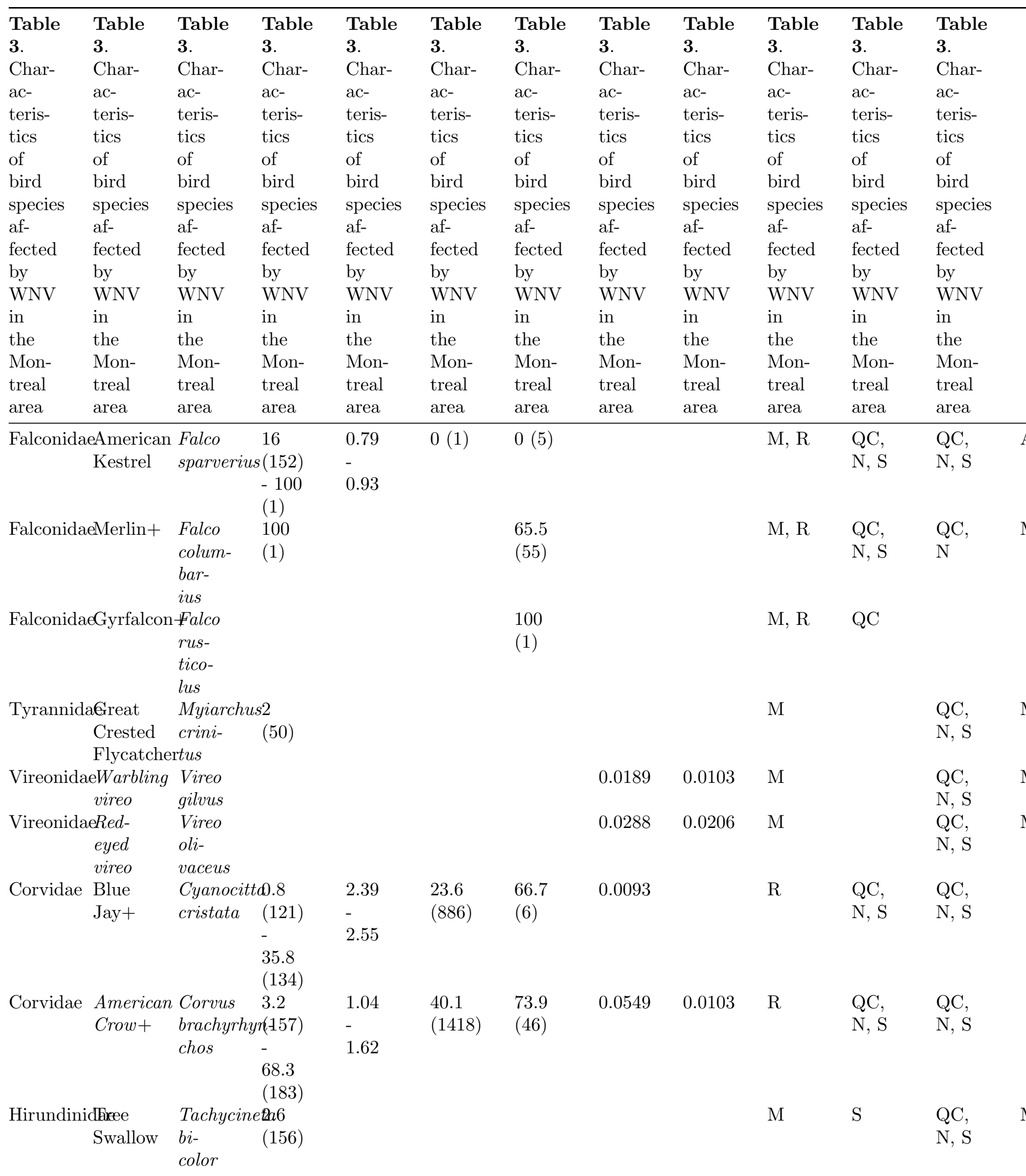




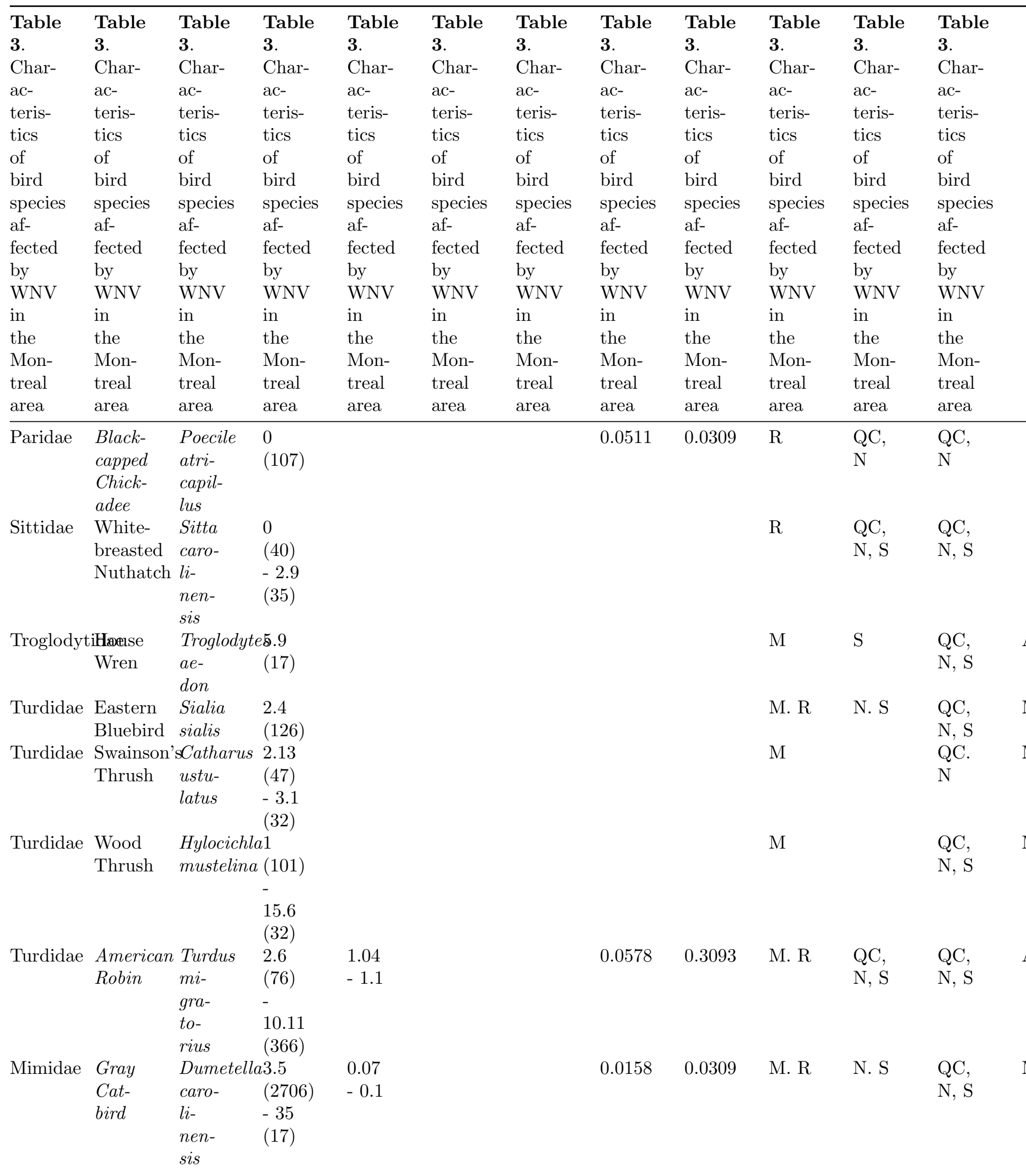




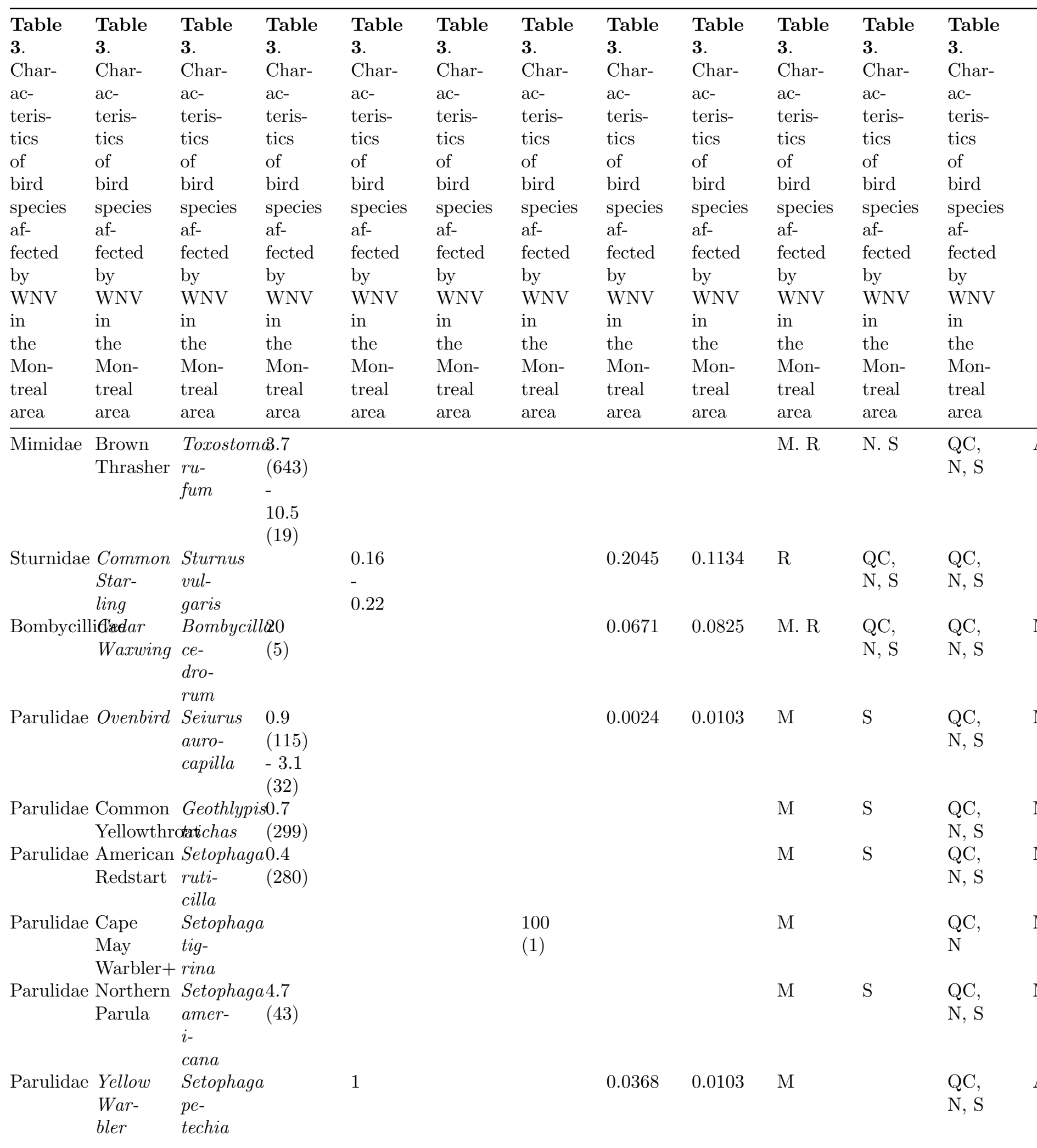




\begin{tabular}{|c|c|c|c|c|c|c|c|c|c|c|c|}
\hline Table & Table & Table & Table & Table & Table & Table & Table & Table & Table & Table & Table \\
\hline 3. & 3. & 3. & 3. & & & & & & 3. & & \\
\hline $\begin{array}{l}\text { Char- } \\
\text { ac- }\end{array}$ & $\begin{array}{l}\text { Char- } \\
\text { ac- }\end{array}$ & $\begin{array}{l}\text { Char- } \\
\text { ac- }\end{array}$ & $\begin{array}{l}\text { Char- } \\
\text { ac- }\end{array}$ & $\begin{array}{l}\text { Char- } \\
\text { ac- }\end{array}$ & $\begin{array}{l}\text { Char- } \\
\text { ac- }\end{array}$ & Char- & $\begin{array}{l}\text { Char- } \\
\text { ac- }\end{array}$ & $\begin{array}{l}\text { Char- } \\
\text { ac- }\end{array}$ & Char- & $\begin{array}{l}\text { Char- } \\
\text { ac- }\end{array}$ & $\begin{array}{l}\text { Char- } \\
\text { ac- }\end{array}$ \\
\hline $\begin{array}{l}\text { ac- } \\
\text { teris- } \\
\text { tics }\end{array}$ & $\begin{array}{l}\text { ac- } \\
\text { teris- } \\
\text { tics }\end{array}$ & $\begin{array}{l}\text { ac- } \\
\text { teris- } \\
\text { tics }\end{array}$ & $\begin{array}{l}\text { ac- } \\
\text { teris- } \\
\text { tics }\end{array}$ & $\begin{array}{l}\text { ac- } \\
\text { teris- } \\
\text { tics }\end{array}$ & $\begin{array}{l}\text { ac- } \\
\text { teris- } \\
\text { tics }\end{array}$ & $\begin{array}{l}\text { ac- } \\
\text { teris- } \\
\text { tics }\end{array}$ & $\begin{array}{l}\text { ac- } \\
\text { teris- } \\
\text { tics }\end{array}$ & $\begin{array}{l}\text { ac- } \\
\text { teris- } \\
\text { tics }\end{array}$ & $\begin{array}{l}\text { ac- } \\
\text { teris- } \\
\text { tics }\end{array}$ & $\begin{array}{l}\text { ac- } \\
\text { teris- } \\
\text { tics }\end{array}$ & $\begin{array}{l}\text { ac- } \\
\text { teris- } \\
\text { tics }\end{array}$ \\
\hline of & of & & of & of & of & of & & & of & & of \\
\hline $\begin{array}{l}\text { bird } \\
\text { species }\end{array}$ & $\begin{array}{l}\text { bird } \\
\text { species }\end{array}$ & $\begin{array}{l}\text { bird } \\
\text { species }\end{array}$ & $\begin{array}{l}\text { bird } \\
\text { species }\end{array}$ & $\begin{array}{l}\text { bird } \\
\text { species }\end{array}$ & $\begin{array}{l}\text { bird } \\
\text { species }\end{array}$ & $\begin{array}{l}\text { bird } \\
\text { species }\end{array}$ & $\begin{array}{l}\text { bird } \\
\text { species }\end{array}$ & $\begin{array}{l}\text { bird } \\
\text { species }\end{array}$ & $\begin{array}{l}\text { bird } \\
\text { species }\end{array}$ & $\begin{array}{l}\text { bird } \\
\text { species }\end{array}$ & $\begin{array}{l}\text { bird } \\
\text { species }\end{array}$ \\
\hline $\begin{array}{l}\text { af- } \\
\text { fected } \\
\text { by }\end{array}$ & $\begin{array}{l}\text { af- } \\
\text { fected } \\
\text { by }\end{array}$ & $\begin{array}{l}\text { af- } \\
\text { fected } \\
\text { by }\end{array}$ & $\begin{array}{l}\text { af- } \\
\text { fected } \\
\text { by }\end{array}$ & $\begin{array}{l}\text { af- } \\
\text { fected } \\
\text { by }\end{array}$ & $\begin{array}{l}\text { af- } \\
\text { fected } \\
\text { by }\end{array}$ & $\begin{array}{l}\text { af- } \\
\text { fected } \\
\text { by }\end{array}$ & $\begin{array}{l}\text { af- } \\
\text { fected } \\
\text { by }\end{array}$ & $\begin{array}{l}\text { af- } \\
\text { fected } \\
\text { by }\end{array}$ & $\begin{array}{l}\text { af- } \\
\text { fected } \\
\text { by }\end{array}$ & $\begin{array}{l}\text { af- } \\
\text { fected } \\
\text { by }\end{array}$ & $\begin{array}{l}\text { af- } \\
\text { fected } \\
\text { by }\end{array}$ \\
\hline WNV & WNV & WNV & WNV & WNV & WNV & WNV & WNV & WNV & WNV & WNV & WNV \\
\hline in & in & in & in & in & in & in & in & in & & & \\
\hline the & & & the & the & the & the & the & the & the & the & the \\
\hline $\begin{array}{l}\text { Mon- } \\
\text { treal } \\
\text { area }\end{array}$ & $\begin{array}{l}\text { Mon- } \\
\text { treal } \\
\text { area }\end{array}$ & $\begin{array}{l}\text { Mon- } \\
\text { treal } \\
\text { area }\end{array}$ & $\begin{array}{l}\text { Mon- } \\
\text { treal } \\
\text { area }\end{array}$ & $\begin{array}{l}\text { Mon- } \\
\text { treal }\end{array}$ & $\begin{array}{l}\text { Mon- } \\
\text { treal }\end{array}$ & $\begin{array}{l}\text { Mon- } \\
\text { treal }\end{array}$ & $\begin{array}{l}\text { Mon- } \\
\text { treal }\end{array}$ & $\begin{array}{l}\text { Mon- } \\
\text { treal }\end{array}$ & $\begin{array}{l}\text { Mon- } \\
\text { treal }\end{array}$ & $\begin{array}{l}\text { Mon- } \\
\text { treal }\end{array}$ & $\begin{array}{l}\text { Mon- } \\
\text { treal }\end{array}$ \\
\hline & area & area & area & area & & area & area & area & area & area & \\
\hline Passerelli & dAdtipping & Spizella & 3 & & & & 0.0652 & 0.0103 & M. R & S & $\mathrm{QC}$, \\
\hline & $\begin{array}{l}\text { Spar- } \\
\text { row }\end{array}$ & $\begin{array}{l}\text { passe- } \\
\text { rina }\end{array}$ & $(59)$ & & & & & & & & $\mathrm{N}, \mathrm{S}$ \\
\hline Passerelli & dSavannah & Passercul & & & & & 0.0021 & 0.0412 & M & S & $\mathrm{QC}$, \\
\hline & $\begin{array}{l}\text { Spar- } \\
\text { row }\end{array}$ & $\begin{array}{l}\text { sand- } \\
\text { wicheris }\end{array}$ & & & & & & & & & $\mathrm{N}$ \\
\hline Passerelli & dfang & Melospiza & & 1.2 & & & 0.0431 & 0.0928 & M. R & $\mathrm{QC}$ & QC, \\
\hline & Spar- & melo- & (13) & & & & & & & $\mathrm{N}, \mathrm{S}$ & $\mathrm{N}, \mathrm{S}$ \\
\hline & row & $d i a$ & $\begin{array}{l}-3.4 \\
(88)\end{array}$ & & & & & & & & \\
\hline Passerelli & dEastern & Pipilo & 0.7 & & & & & & M & N. S & $\mathrm{QC}$, \\
\hline & Towhee & ery- & $(144)$ & & & & & & & & $\mathrm{N}, \mathrm{S}$ \\
\hline & & $\begin{array}{l}\text { throph- } \\
\text { thal- }\end{array}$ & $\begin{array}{l}-9.6 \\
(197)\end{array}$ & & & & & & & & \\
\hline & & mus & & & & & & & & & \\
\hline Cardinali & dSearlet & Piranga & 2.8 & & & & & & M & & $\mathrm{QC}$, \\
\hline & Tanager & $\begin{array}{l}\text { oli- } \\
\text { vacea }\end{array}$ & (71) & & & & & & & & $\mathrm{N}, \mathrm{S}$ \\
\hline Cardinal & dAferthern & Cardinali & $s 6.2$ & 0.38 & & & 0.0313 & 0.0309 & $\mathrm{R}$ & $\mathrm{QC}$, & $\mathrm{QC}$ \\
\hline & Car- & car- & $(503)$ & & & & & & & $\mathrm{N}, \mathrm{S}$ & $\mathrm{N}, \mathrm{S}$ \\
\hline & dinal & $d i-$ & - & & & & & & & & \\
\hline & & nalis & $\begin{array}{l}52.2 \\
(115)\end{array}$ & & & & & & & & \\
\hline Cardinali & dRese- & Pheucticu & & & & & & & M & & QC. \\
\hline & breasted & $l u-$ & (98) & & & & & & & & $\mathrm{N}$ \\
\hline & Grosbeak & $\begin{array}{l}\text { dovi- } \\
\text { cianus }\end{array}$ & $\begin{array}{l}-5 \\
(22)\end{array}$ & & & & & & & & \\
\hline Cardinali & drredigo & Passerina & 3.6 & & & & & & M & S & $\mathrm{QC}$, \\
\hline & Bunting & cyanea & $(28)$ & & & & & & & & $\mathrm{N}, \mathrm{S}$ \\
\hline & & & $\begin{array}{l}-2.2 \\
(223)\end{array}$ & & & & & & & & \\
\hline Icteridae & Eastern & Sturnella & 100 & & & & & & M & N. S & $\mathrm{QC}$, \\
\hline & Meadowla & unkagna & (1) & & & & & & & & $\mathrm{N}, \mathrm{S}$ \\
\hline
\end{tabular}




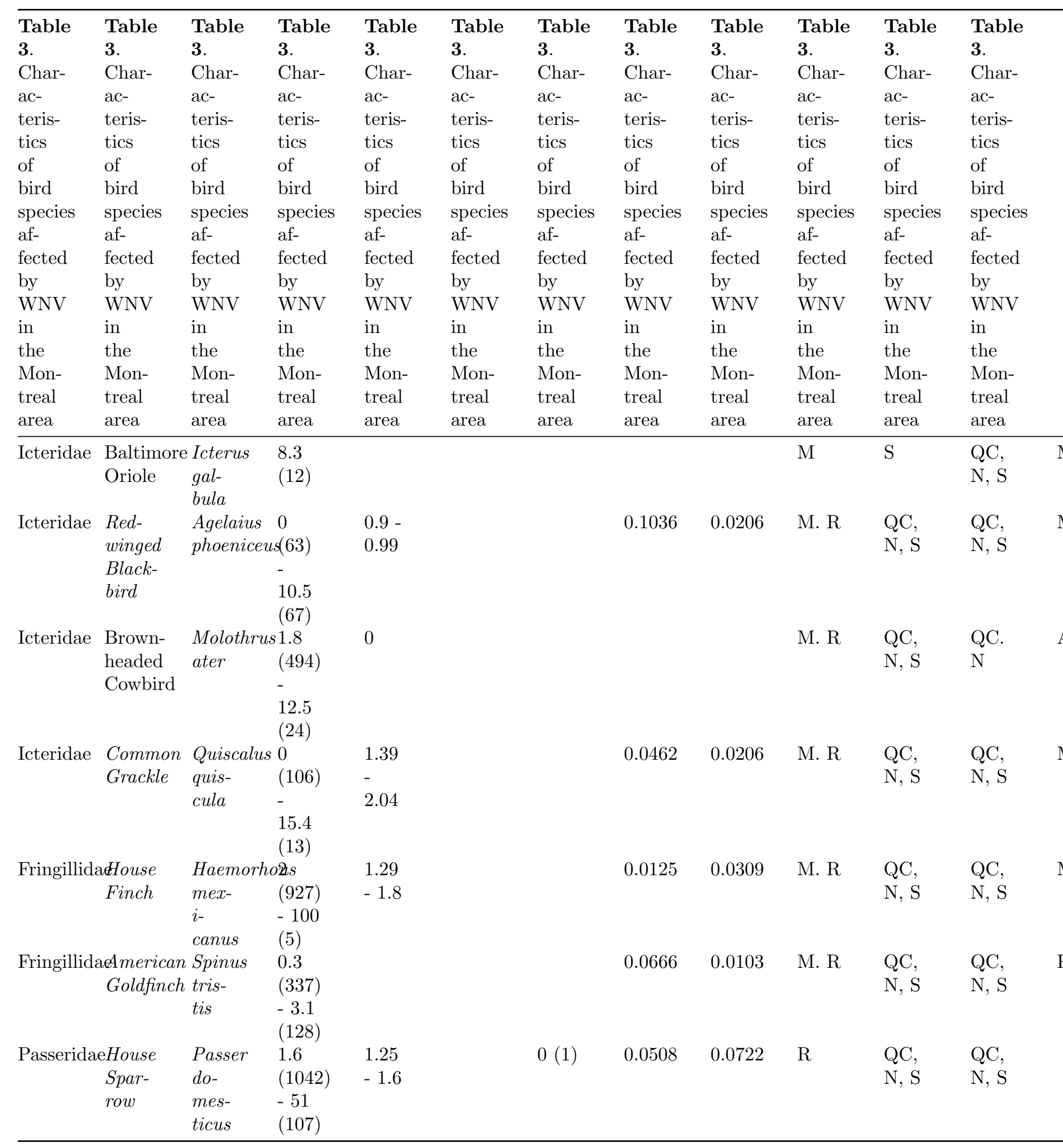

Species $=$ bird species for which blood meal data are available in our study area $(\mathrm{n}=20) ;+=$ bird species 
for which mortality data are available in available study area $(\mathrm{n}=18) ;{ }^{1}$ Minimum and maximum percentages of WNV sero-positive birds ( $\mathrm{n}=$ sample size) (Komar et al. 2001, Ringia et al. 2004, Godsey et al. 2005, Komar et al. 2005, Gibbs et al. 2006, Dusek et al. 2009, Loss et al. 2009, Dubé et al. 2010, Chuang et al. 2011, Kilpatrick et al. 2013, Komar et al. 2013, Randall et al. 2013); ${ }^{2}$ Minimum and maximum index of host competence for WNV (Komar et al. 2003, Kilpatrick et al. 2007, Wheeler et al. 2009); ${ }^{3}$ Percentage of dead birds positive to WNV ( $\mathrm{n}=$ sample size) (CWHC); ${ }^{4} a_{s}$ is the density of species $s$ divided by the total density of the avian community, data come from the EPOQ database. The sum of all $a_{s}$ is equal to one; ${ }^{5}$

$f_{i}$ is the fraction of total blood meals taken by Cx. pipiens-restuans from host $s$ (INSPQ 2016). The sum of all $f_{i}$ is equal to one ${ }^{6}=\mathrm{M}$ : Migratory bird species; R: Resident bird species; ${ }^{7}=$ S: South USA; N: North USA; QC: Quebec.

\section{Figure captions}

Figure 1. Yearly number of cases of West Nile virus (WNV) infection in humans and number of dead birds positive to WNV in Quebec 2002 - 2017. Insert: Correlation between the number of West Nile virus cases diagnosed in birds and the number of cases of WNV observed in humans in Quebec (log scales).

Figure 2. Study area with locations of collection of dead birds (CWHC), bird watching and counts (EPOQ), and collection of femaleCx. pipiens-restuans on the island of Montreal, Quebec.

Figure 3. List $\mathrm{L}_{1}$ : ranked list $(\mathrm{n}=18)$ of dead birds found by WNV passive bird surveillance. $\mathrm{RR}$ stands for relative risk or ratio of dead birds positive to WNV. Quoted letters "M" and "R" stand for migratory and resident birds, respectively.

Figure 4. List $\mathrm{L}_{2}$ : ranked list $(\mathrm{n}=23)$ of bird species found from analysis of Cx. pipiens-restuans blood meals. Left panel: Relative abundance $\left(n \times a_{s}\right)$ of bird species and relative feeding (fraction of Cx. pipiensrestuans blood meals) $\left(n \times f_{s}\right)$. Dashed vertical lines at relative abundance and feeding " 1 " represent the ratio " $1 / \mathrm{n}$ " where $\mathrm{n}=23$ is the bird species diversity. Right panel: relative host preference $\left(n \times p_{s}\right)$ of $C x$. pipiens-restuans . Quoted letters " $\mathrm{M}$ " and " $\mathrm{R}$ " stand for migratory and resident birds, respectively.

Figure 5. Proportion of Culex pipiens-restuans blood meals taken from birds of all species by week. Data points correspond to field data and the solid line through the data to the predicted proportions using the logistic regression model.

Figure 6. Selection process and result of the literature review.

Figure 7. List $\mathrm{L}_{3}$ : ranked list $(\mathrm{n}=53)$ of bird species found from the literature review. $\mathrm{RR}$ stands for relative risk or ratio of sero-positives. Quoted letters " $\mathrm{M}$ " and "R" stand for migratory and resident birds, respectively. 

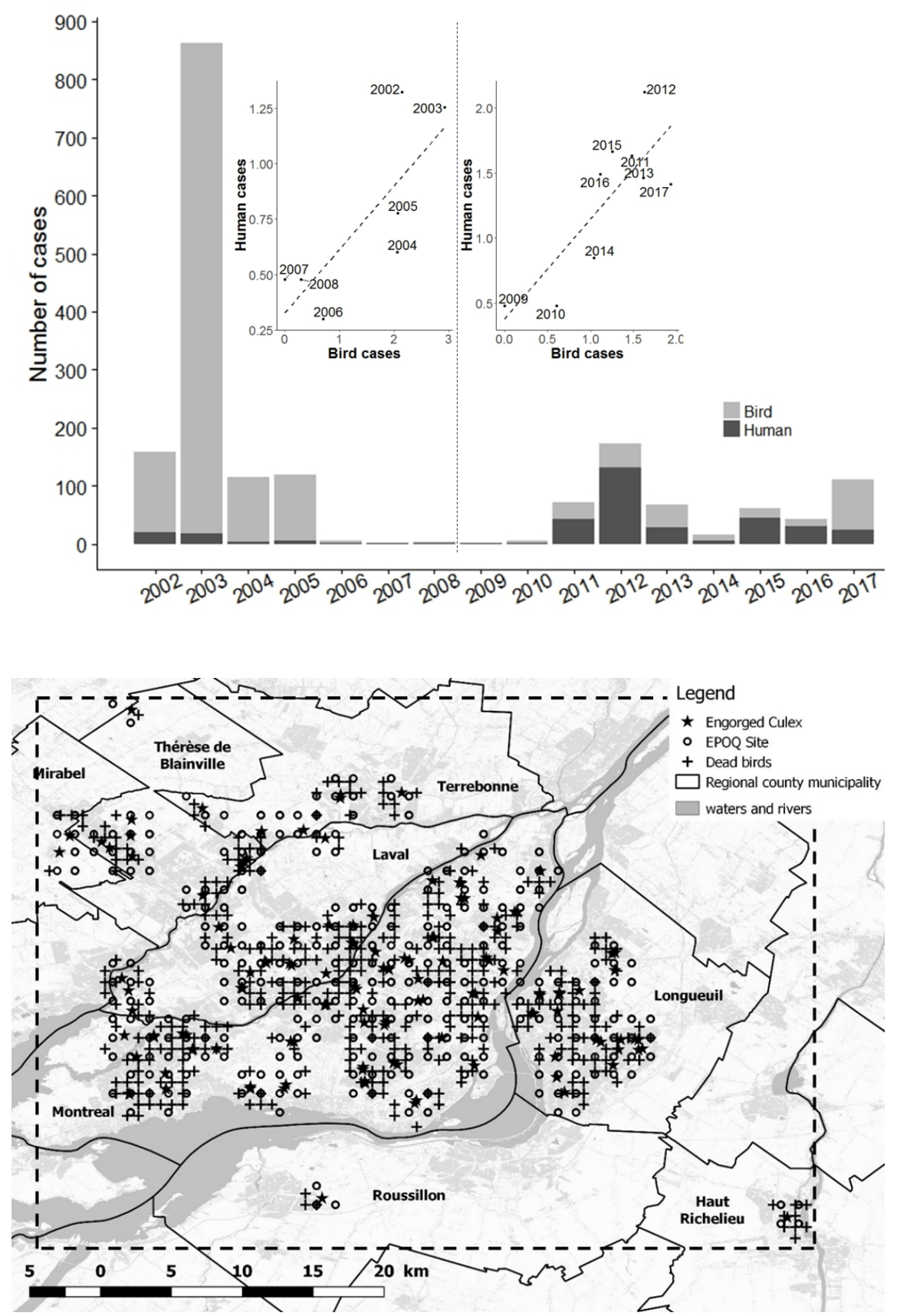

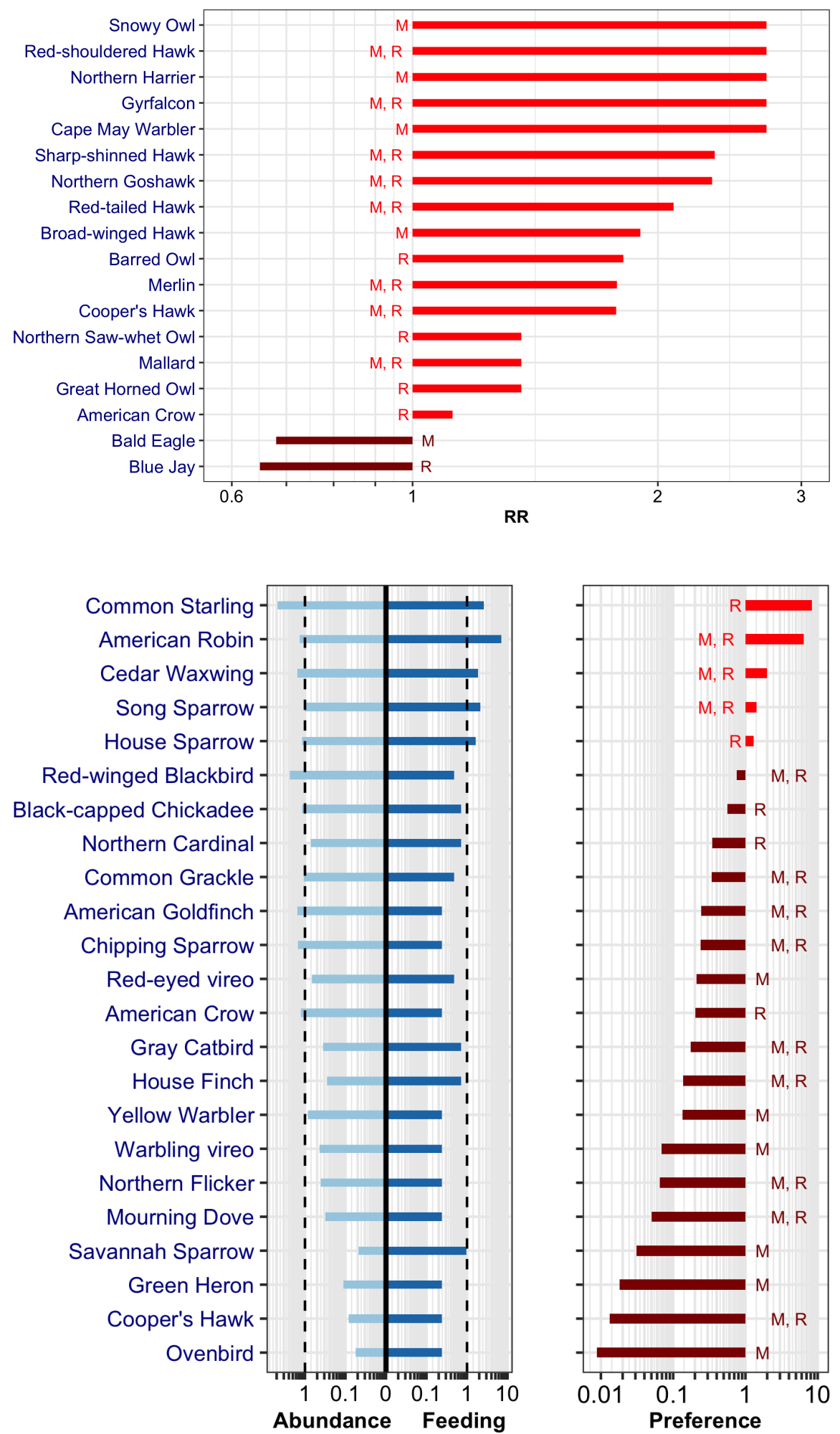

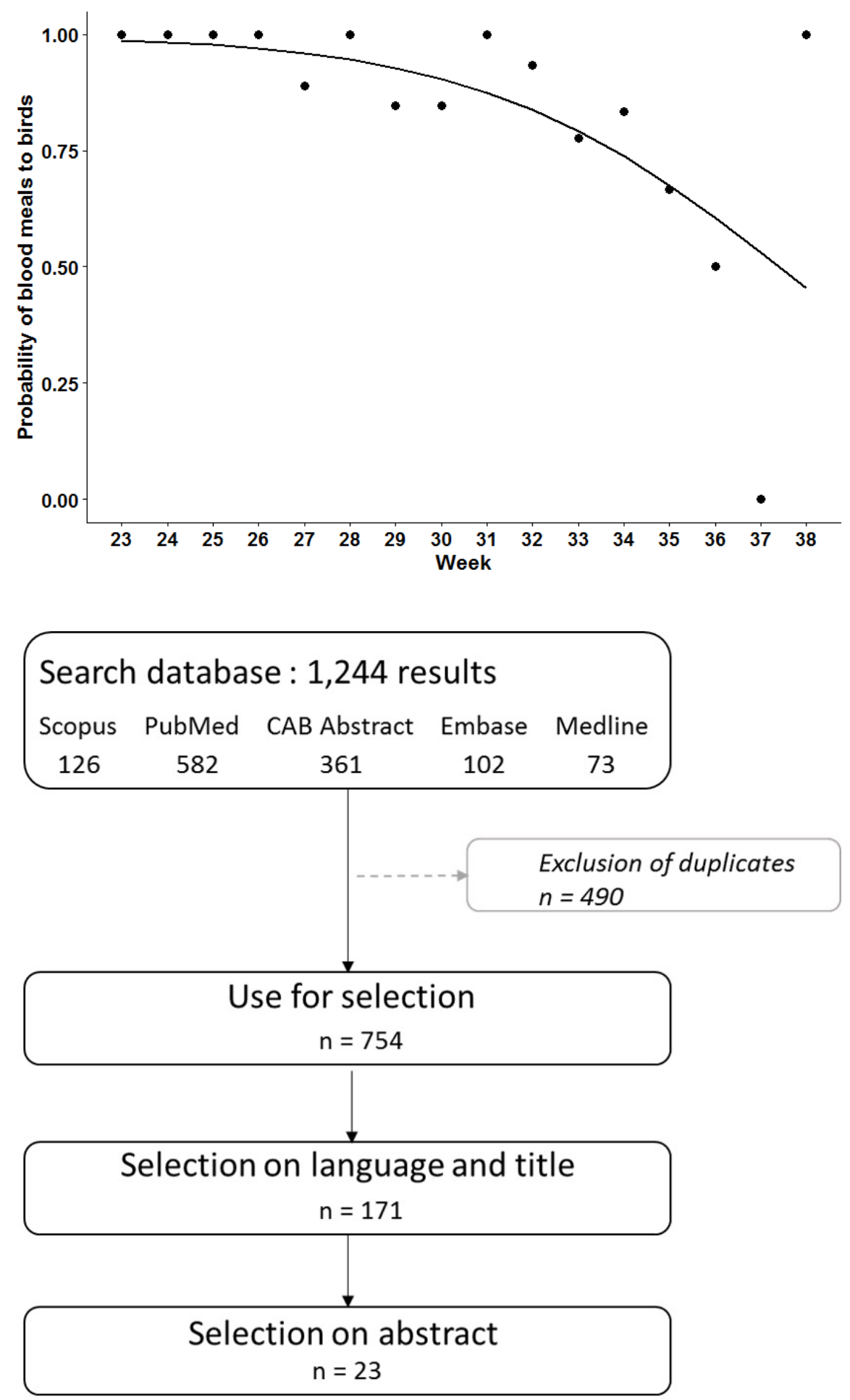


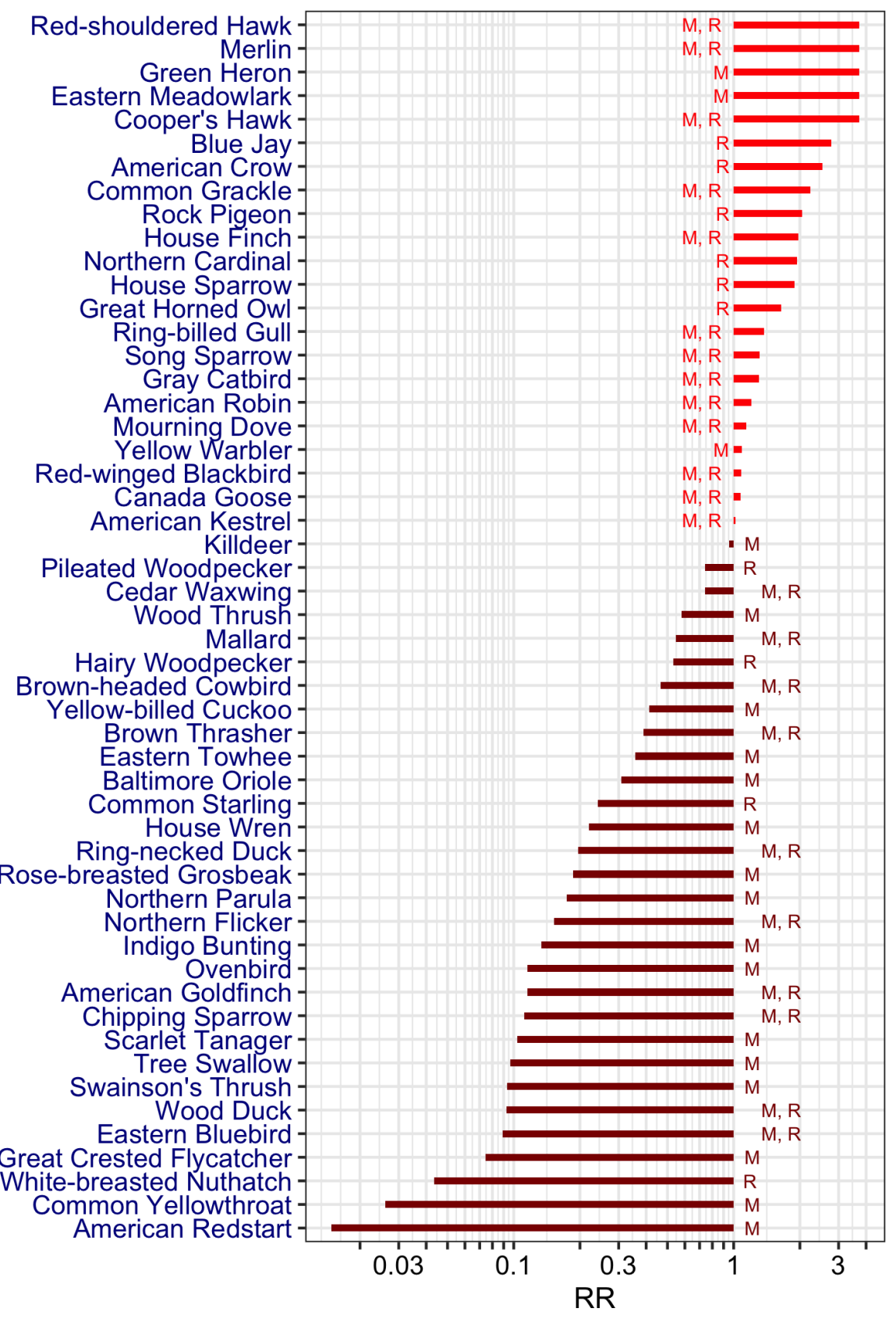

